\title{
Mixing states of Amazon basin aerosol particles transported over long distances using transmission electron microscopy
}

\author{
Kouji Adachi $^{1}$, Naga Oshima ${ }^{1}$, Zhaoheng Gong ${ }^{2, a}$, Suzane de Sá $^{2}$, Adam P. Bateman $^{2}$, Scot T. Martin $^{2}$, \\ Joel F. de Brito ${ }^{3, b}$, Paulo Artaxo ${ }^{3}$, Glauber G. Cirino ${ }^{4, c}$, Arthur J. Sedlacek III $^{5}$, and Peter R. Buseck ${ }^{6}$ \\ ${ }^{1}$ Department of Atmosphere, Ocean and Earth System Modeling Research, Meteorological Research Institute, \\ Tsukuba, Japan \\ ${ }^{2}$ School of Engineering and Applied Sciences \& Department of Earth and Planetary Sciences, Harvard University, \\ Cambridge, Massachusetts, USA \\ ${ }^{3}$ Institute of Physics, University of São Paulo, São Paulo, Brazil \\ ${ }^{4}$ National Institute for Amazonian Research, Manaus, Amazonas, Brazil \\ ${ }^{5}$ Brookhaven National Laboratory, Upton, New York, USA \\ ${ }^{6}$ School of Earth and Space Exploration \& School of Molecular Sciences, Arizona State University, Tempe, Arizona, USA \\ anow at: Harvard Business School, Boston, Massachusetts, USA \\ b now at: IMT Lille Douai, University of Lille, SAGE, Lille 59000, France \\ ${ }^{\mathrm{c}}$ now at: Geosciences Institute, Federal University of Pará, Belém, Brazil
}

Correspondence: Kouji Adachi (adachik@mri-jma.go.jp)

Received: 8 May 2020 - Discussion started: 4 June 2020

Revised: 24 August 2020 - Accepted: 10 September 2020 - Published: 23 October 2020

\begin{abstract}
The Amazon basin is important for understanding the global climate because of its carbon cycle and as a laboratory for obtaining basic knowledge of the continental background atmosphere. Aerosol particles play an important role in the climate and weather, and knowledge of their compositions and mixing states is necessary to understand their influence on the climate. For this study, we collected aerosol particles from the Amazon basin during the Green Ocean Amazon (GoAmazon2014/5) campaign (February to March 2014) at the T3 site, which is located about $70 \mathrm{~km}$ from Manaus, and analyzed them using transmission electron microscopy (TEM). TEM has better spatial resolution than other instruments, which enables us to analyze the occurrences of components that attach to or are embedded within other particles. Based on the TEM results of more than 10000 particles from several transport events, this study shows the occurrences of individual particles including compositions, size distributions, number fractions, and possible sources of materials that mix with other particles. Aerosol particles during the wet season were from both natural sources such as the Amazon forest, Saharan desert, Atlantic Ocean, and African biomass burning and anthropogenic sources such as Manaus and lo-
\end{abstract}

cal emissions. These particles mix together at an individual particle scale. The number fractions of mineral dust and seasalt particles increased almost 3-fold when long-range transport (LRT) from the African continent occurred. Nearly $20 \%$ of mineral dust and primary biological aerosol particles had attached sea salts on their surfaces. Sulfates were also internally mixed with sea-salt and mineral dust particles. The TEM element mapping images showed that several components with sizes of hundreds of nanometers from different sources commonly occur within individual LRT aerosol particles. We conclude that many aerosol particles from natural sources change their compositions by mixing during transport. The compositions and mixing states of these particles after emission result in changes in their hygroscopic and optical properties and should be considered when assessing their effects on climate. 


\section{Introduction}

The Amazon basin can exhibit clean atmospheric conditions at times during the wet season and thus is uniquely useful for understanding aerosol particles from natural background sources (Martin et al., 2010a, 2016). Natural aerosol particles are important for meteorological and climatological influences on this region. Knowledge of background atmospheric conditions is critical for understanding preindustrial conditions and, in turn, the climate changes caused by human activity (Andreae, 2007; Carslaw et al., 2013; Wang et al., 2016a). To understand the sources, abundances, sizes, and compositions of Amazon aerosol particles, various atmospheric measurements have been conducted such as the Amazonian Aerosol Characterization Experiment 2008 (AMAZE-2008), South American Biomass Burning Analysis (SAMBBA), and the Green Ocean Amazon (GoAmazon2014/5) campaigns (Andreae et al., 2015; Bateman et al., 2015; Brito et al., 2014; Cirino et al., 2018; Martin et al., 2010a, 2016, 2017). As a result, long-range transport (LRT) from Africa and the Atlantic Ocean was established as an important pathway for mineral dust (hereafter mineral) and sea salt to the Amazon during the wet season (Artaxo et al., 1990; Artaxo and Hansson, 1995; Formenti et al., 2001; Krejci et al., 2005; Moran-Zuloaga et al., 2018; Wang et al., 2016b; Worobiec et al., 2007). Biological emissions are also being recognized as possible sources of inorganic salt particles containing elements such as $\mathrm{K}$ and $\mathrm{Na}$ (Pöhlker et al., 2012; China et al., 2018). These particles are mixed within individual particles, and, thus, observations of their occurrence at sizes of hundreds of nanometers or smaller are needed to understand their mixing processes in the atmosphere.

Aerosol particles coagulate and can become coated by volatile organic compounds or acid gas condensation. Such changes affect particle mixing states and compositions (Adachi and Buseck, 2008). The mixing states can significantly affect particle hygroscopicity, optical properties, and compositions (Adachi et al., 2010, 2011; Cappa et al., 2012; Fraund et al., 2017). It is important to understand and evaluate particle mixing states to accurately simulate the influences of aerosol particles on the climate (Oshima et al., 2009).

Transmission electron microscopy (TEM) is well suited for determining the shapes, mixing states, and compositions of individual particles smaller than $2 \mu \mathrm{m}$ ( $\mathrm{Li}$ et al., 2016). TEM measurements have both advantages and limitations relative to other analytical methods. The advantages of TEM analyses are that they can measure particles smaller than several hundred nanometers, which is the predominant size in terms of particle number concentration. To date, studies have analyzed individual particle compositions from samples collected from the Amazon basin using scanning electron microscopy (SEM), scanning transmission X-ray microscopy (STXM), and electron probe X-ray microanalysis (EPMA) (e.g., Worobiec et al., 2007; Fraund et al., 2017; Krejci et al., 2005; China et al., 2018; Huffman et al., 2012; Wu et al., 2019). Although each instrument has its advantages and limitations, TEM has better spatial resolution $(\sim 0.1 \mathrm{~nm}$; Li et al., 2016) than other instruments, which enables us to analyze the shapes and compositions of components tens to hundreds of nanometers in size that attach to other particles. Furthermore, TEM analyses can image the internal structures of individual particles. TEM can also measure refractory materials that are difficult or impossible to detect using other methods, for example, certain types of online aerosol mass spectrometry. Limitations of TEM measurement include it only being used for particles on substrates, resulting in a loss of volatile material during sampling and analysis, interference from the substrate, and a lower time resolution than that of online instruments.

The GoAmazon2014/5 campaign was conducted in 2014 and 2015 and aimed to address questions related to climate processes, perturbations from human activities, and the terrestrial ecosystem in the Amazon basin (Martin et al., 2016). Our study focused on TEM samples collected during intensive observation period 1 (IOP1) from 1 February to 31 March 2014. The goals of this study are to characterize individual aerosol particles collected from the central Amazon basin during the wet season and to measure these particle occurrences and detailed mixing states at an individual particle level for implications regarding their regional emissions, regional- to hemispheric-scale transport, particle mixing processes, and climate effects.

\section{Methods}

\subsection{Campaign and sampling}

During the GoAmazon2014/5 campaign, atmospheric measurements were conducted at nine research sites and using two aircraft (Martin et al., 2016). We mainly collected TEM samples at the $\mathrm{T} 3$ site $\left(3.2133^{\circ} \mathrm{S}, 60.5987^{\circ} \mathrm{W}\right)$, which is $70 \mathrm{~km}$ from Manaus and was the most comprehensively instrumented site including the Atmospheric Radiation Measurement (ARM) Mobile Facility One (AMF-1) and the ARM Mobile Aerosol Observing System (MAOS) (Mather and Voyles, 2013). The details of the campaign are described in Martin et al. (2016).

TEM sampling during IOP1 was conducted at the MAOS container using a shared inlet. We used a TEM aerosol sampler (AS-16W, Arios, Tokyo, Japan) with two impactor stages that collect particles with $\sim 0.1-0.7 \mu \mathrm{m}$ aerodynamic diameter (50\% cutoff diameter) on the fine-mode stage and greater than $0.7 \mu \mathrm{m}$ on the coarse-mode stage. In this study, we used fine-stage samples to focus on fine-mode particles that are abundant in number but have not been analyzed in detail in this area using TEM. The sampler can mount 16 TEM grids (200 mesh $\mathrm{Cu}$ grids with lacey carbon substrates; Ted Pella, CA, USA, type 01881) attached to an aluminum plate 
that rotates with a preset timer. The lacey carbon substrates minimize interference from the substrate during the particle composition measurements and a spread of liquid particles over the substrate. We used 30 min collection times at a $1.0 \mathrm{~L} \mathrm{~min}^{-1}$ flow rate to have an appropriate particle number concentration on the substrates. We collected samples at $2.5 \mathrm{~h}$ intervals, i.e., eight samples per day from 1 February to 31 March 2014 ( 500 TEM samples total).

\subsection{TEM analysis}

We used a $120 \mathrm{kV}$ transmission electron microscope (JEM1400, JEOL, Tokyo, Japan) with a scanning mode (scanning transmission electron microscopy; STEM) equipped with an energy-dispersive X-ray spectrometer (EDS; X-max 80, Oxford Instruments, Tokyo, Japan). We obtained representative TEM images of all grid samples ( 30 TEM images per sample). Then, 54 samples were selected for individual particle analyses based on the TEM images to cover the sampling periods with high mineral particle fractions and other periods of interest, for example, pollution period and periods of dominant primary biological aerosol (PBA). These periods were compared with the model experiments and the observations using a high-resolution time-of-flight aerosol mass spectrometer (de Sá et al., 2018) and were classified into LRT, pollution, and background periods (Fig. 1).

Semiautomated particle analysis with 20 s of EDS measurements was used for individual particle analyses. The same measurements yielded particle sizes (area-equivalent diameters) from segmented binary images. As some particles (e.g., sulfate) can be damaged by electron beam exposure during the EDS analysis, we used the STEM images taken before the EDS measurements for the size measurements. Here, the geometric diameters (area-equivalent diameter) can be larger than the aerodynamic diameters when particles are flat or have low densities, and bouncing from the coarse stage to the fine stage is possible (Bateman et al., 2017). As a result, although the sampler collects particles with an aerodynamic diameter of $\sim 0.1-0.7 \mu \mathrm{m}$, we have particles of up to $3 \mu \mathrm{m}$ in area-equivalent diameter. During the STEM-EDS analyses, we analyzed all particles larger than $180 \mathrm{~nm}$ to measure more than 200 particles per sample. We randomly chose two to seven areas that did not have too many particles with a magnification of $6000(23 \mu \mathrm{m} \times 23 \mu \mathrm{m})$ to avoid particles that overlap on the substrate. Each field of view includes $\sim 74$ particles on average, resulting in $\sim 7 \%$ of the particle area among the field of views. As a result, we reduced the chance of analyzing particles that agglomerate on the substrate. Nevertheless, it is still possible that some particles overlapped on the substrates. We evaluate that the overestimation for the number fraction measurements of internally mixed particles is less than $10 \%$ based on the particle area fractions. Detailed information of the analysis is also described in Adachi et al. $(2018,2019)$ and Ching et al. (2019).
Measured particles were classified into seven categories based on their compositions, i.e., particles containing both $\mathrm{Al}$ and $\mathrm{Fe}$ as a proxy of mineral particles, $\mathrm{P}$-bearing particles as a proxy of PBA particles, Na-bearing particles as a proxy of sea salt and biological salt, S-bearing particles as a proxy of sulfate, K-bearing particles as a proxy of potassium salt, Crich particles as a proxy of carbonaceous particles, and others (Fig. S1 in the Supplement). As Na-bearing particles can include both marine and biological sources, as proposed by China et al. (2018), we use "sea salt" for those having specific $\mathrm{Mg}$ and $\mathrm{Na}$ ratios $(0.05<\mathrm{Mg} / \mathrm{Na}<0.3)$ (Fig. S1). Particles that fall into more than two types (e.g., mineral plus sulfate) were classified into the upper categories in the flow chart presented in Fig. S1. We checked their shapes individually and confirmed that most particles were classified appropriately. Exceptions that were categorized as "other" totalled $\sim 3 \%$ of all particles and included metal, fly ash, and mineral particles without $\mathrm{Al}$ and Fe (Fig. 2). Nanosphere soot (ns-soot) particles are defined by their aggregated nanosphere structure and the graphitic-like microstructures observed using TEM (Buseck et al., 2014). They are grouped into the carbonaceous category because they do not have characteristic elements other than $\mathrm{C}$.

\subsection{Model description}

We used the Meteorological Research Institute Earth System Model version 2 (MRI-ESM2; Yukimoto et al., 2019; Oshima et al., 2020) to evaluate the LRT periods and the sources and transport of LRT mineral particles to the Amazon basin (Figs. 3 and 4). For this study, we modified the original model configuration and used only atmospheric (the atmospheric general circulation model, AGCM, with land processes, MRI-AGCM3.5) and aerosol (the Model of Aerosol Species in the Global Atmosphere mark-2, MASINGAR mk2) component models. The model employs horizontal resolutions with an approximately $120 \mathrm{~km}$ grid (TL159) and 80 vertical layers from the surface to a model top of $0.01 \mathrm{hPa}$ in a hybrid sigma-pressure coordinate system. The model simulation was performed from January 2008 to December 2015 after a 1-year spin-up run using the prescribed sea surface temperature data (Ishii et al., 2005). In the model simulation, the horizontal wind fields in the AGCM were nudged towards the 6-hourly Japanese 55-year reanalysis data (Kobayashi et al., 2015). We used the monthly anthropogenic emissions dataset of Lamarque et al. (2010) and the daily biomassburning emissions from the global fire assimilation system dataset of Kaiser et al. (2012). Mineral (dust) and sea-salt emissions were calculated depending on the meteorological conditions in the model (Tanaka and Chiba, 2005; Yumimoto et al., 2017). 
(a)

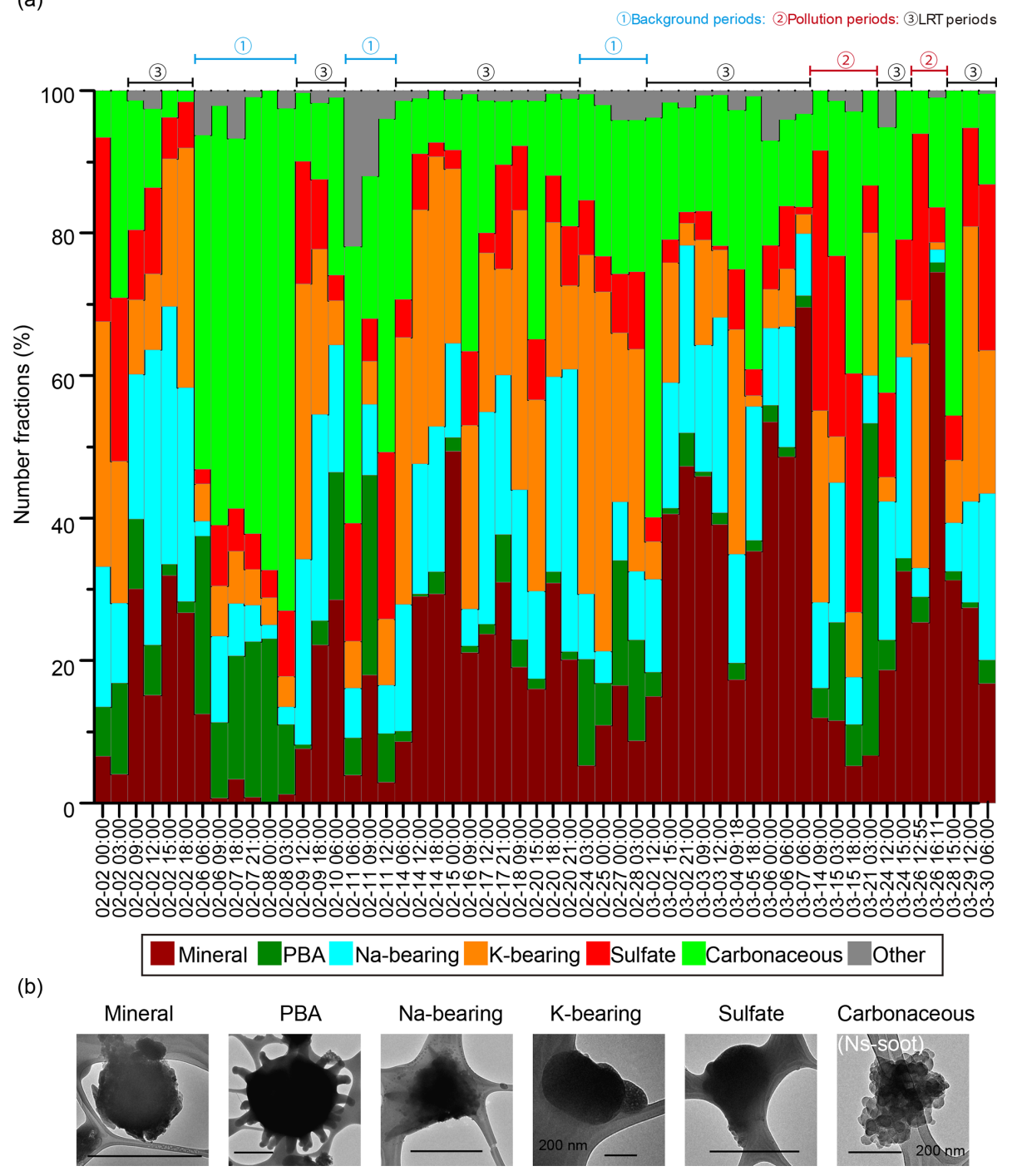

Figure 1. Number fractions of each aerosol particle type for all analyzed samples (a) and the representative TEM images of each particle type (b). The scale bars for mineral, PBA, Na-bearing, and sulfate particles are $1 \mu \mathrm{m}$, and those for K-bearing and carbonaceous particles are $200 \mathrm{~nm}$. Compositions and low-magnification images of these particles are shown in Fig. S2 (mineral), Fig. S5 (PBA), Fig. 11 (Na-bearing), Fig. S7 (K-bearing), Fig. S8 (sulfate), and Fig. S7 (carbonaceous). Samples were divided into LRT and other periods (bars in panel a). Other periods were further divided into pollution periods (14, 15, and 26 March 2014) and background periods (all other periods except the pollution periods and 2 February 2014) based on the classifications of de Sá et al. (2018). Samples collected on 2 February were outside of the measurement period of de Sá et al. (2018).

\section{Results and discussion}

\subsection{Model simulation}

The model simulation characterized six LRT periods that had mineral dust concentration peaks greater than $10 \mu \mathrm{g} \mathrm{m}^{-3}$ during IOP1 (Fig. 3). The LRT periods cover the high mineral particle samples of the TEM analysis, and we identify these TEM samples as LRT samples. These periods also generally overlap with those of Moran-Zuloage et al. (2018) who measured aerosol mass concentrations from 1 to $10 \mu \mathrm{m}$ (coarse mode) at the Amazon Tall Tower Obser- vatory (ATTO) during the campaign, and they are consistent with the dust events from the MODIS satellite observations (https://worldview.earthdata.nasa.gov/, last access: 20 October 2020). The model simulation shows the horizontal distributions of mineral dust concentrations at the surface level during the six LRT periods and the vertical distributions on 7 March when the largest LRT periods occurred during IOP1 (Fig. 4). The model results indicate that these mineral dust particles originated from the Saharan desert, followed by easterly transport in the lower troposphere over the Atlantic Ocean to the Amazon basin. 
(a) Long-range transport period samples

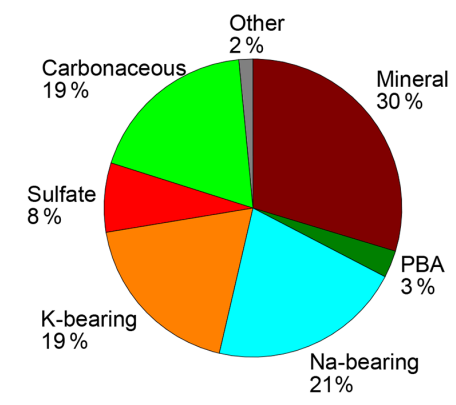

(c) Pollution period samples

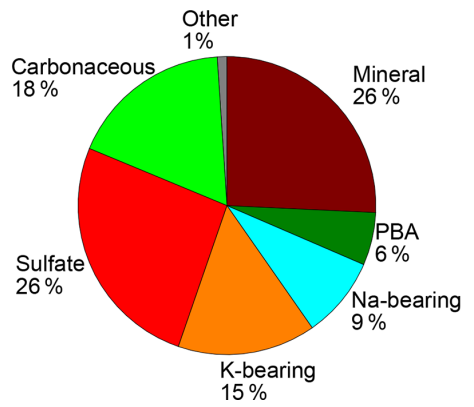

(b) Other period samples

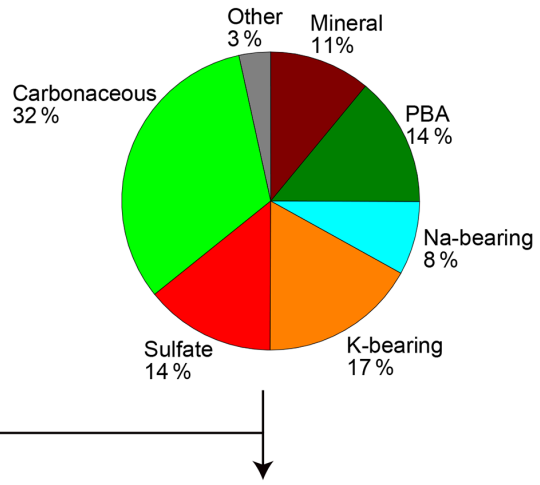

(d) Background period samples

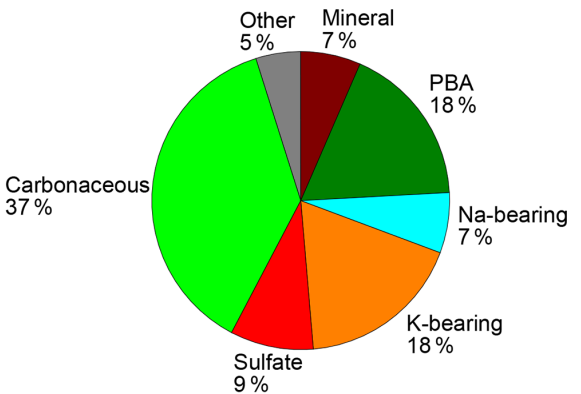

Figure 2. Number fractions of each aerosol particle type for average values during the (a) LRT period and (b) other period samples. Other periods were further divided into (c) pollution periods (14, 15, and 26 March 2014) and (d) background periods. See Fig. 1 for the sample classifications.

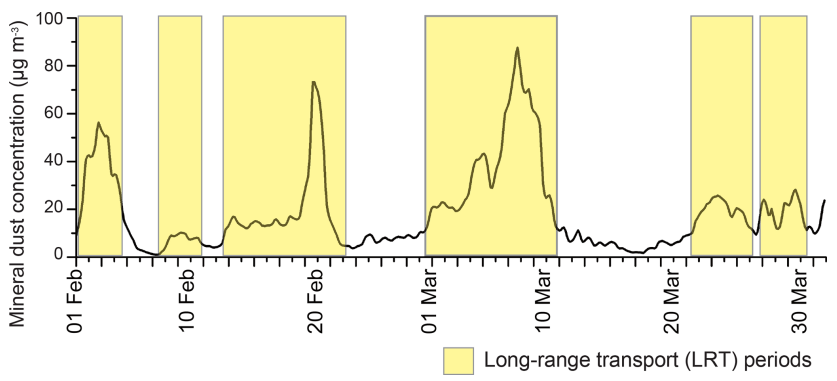

Figure 3. Model simulations of temporal variation of mineral dust mass concentrations at the T3 site. Yellow screens show LRT periods.

\subsection{Shapes, compositions, and sizes of aerosol particles}

Representative particle images with elemental maps (e.g., Figs. S2-S10), size distributions, and size-dependent number fractions for each particle category (Fig. 5) were analyzed with TEM. Here, we show the sizes, shapes, and mixing states of individual particles for each particle type.

\subsubsection{Mineral particles}

Tens of teragrams per year of mineral particles from the Saharan desert are transported to the Amazon basin (Graham et al., 2003; Swap et al., 1992; Wang et al., 2016b; Yu et al., 2015) and provide $\mathrm{Fe}$ and $\mathrm{P}$ nutrients for forests (Bristow et al., 2010). Such mineral particles also contribute to icenucleating particles (INPs) to form ice clouds (Prenni et al., 2009).

Mineral particles were defined as those containing both $\mathrm{Al}$ and $\mathrm{Fe}$, although $\mathrm{Na}, \mathrm{Si}, \mathrm{Ca}, \mathrm{S}$, and $\mathrm{K}$ were also detected in most mineral particles (Figs. 6 and S2). These particles are typically crystalline, appear darker than other particles, and have irregular edges in TEM images (Fig. 6). They have a broad size distribution with a relatively large modal peak $(\sim 1.3-1.6 \mu \mathrm{m}$ in area-equivalent diameter) (Fig. 5). The number fractions sporadically increase (Fig. 1), coordinating with LRT from Africa in the model (Figs. 3 and 4).

Most mineral particles consist of Al- and Si-bearing clay minerals (e.g., illite and kaolinite). These minerals are aggregated with other minerals such as quartz (Si-O), K-feldspar (K-Al-Si), and small $(\sim 100 \mathrm{~nm})$ grains that contain $\mathrm{Fe}$ and $\mathrm{O}$ or $\mathrm{Ca}$ and S (Figs. 6 and S2). The average weight percent (wt \%) of $\mathrm{Al}$ and $\mathrm{Si}$ in mineral particles in each sample shows a positive correlation for samples from both LRT and other periods (Fig. 7). The values for $\mathrm{Si} / \mathrm{Al}$ between 1.5 and 3 for LRT period samples are roughly consistent with bulk measurements of Amazon aerosol in other studies (Artaxo et al., 2002; Caquineau et al., 1998; Martin et al., 2010b; Moran- 
(a)

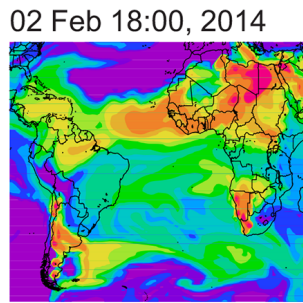

19 Feb 18:00, 2014

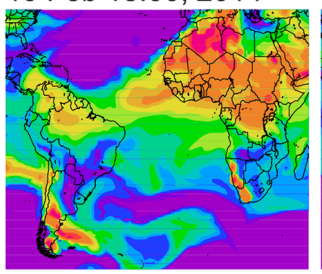

23 Mar 12:00, 2014

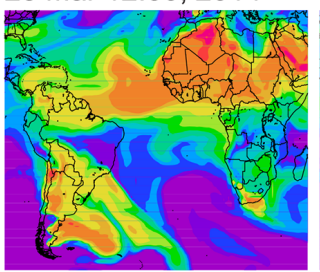

Mineral dust concentration ( $\mu \mathrm{g} \mathrm{m}-3$ )
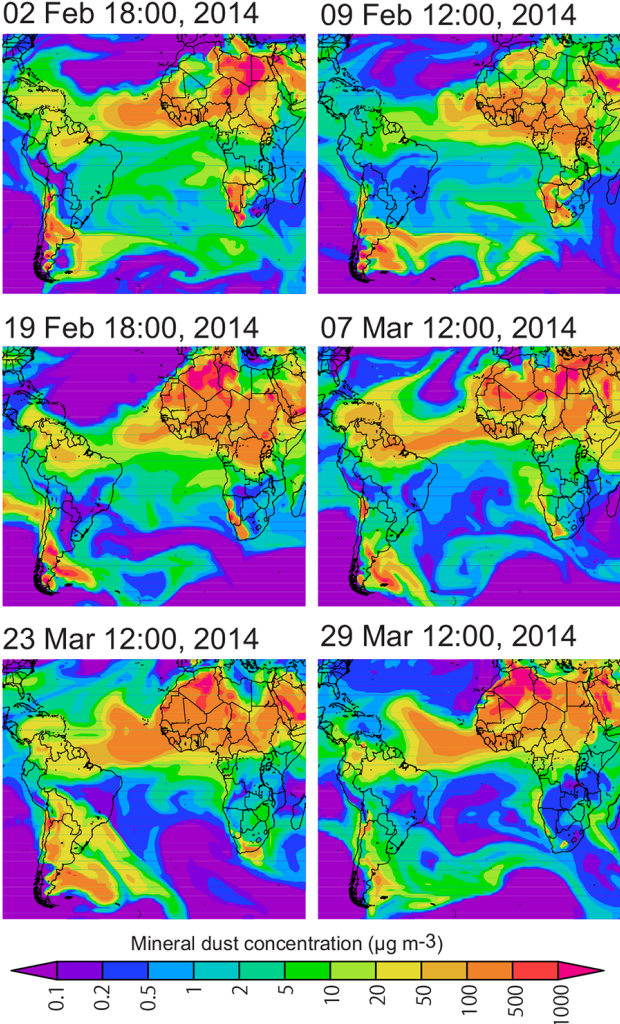

07 Mar 12:00, 2014

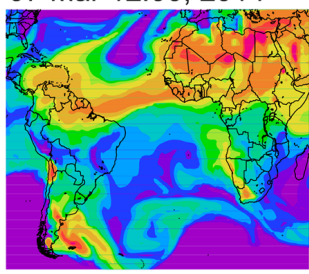

29 Mar 12:00, 2014 (b)

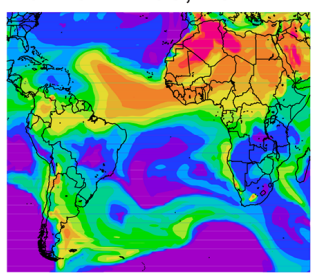

(c)
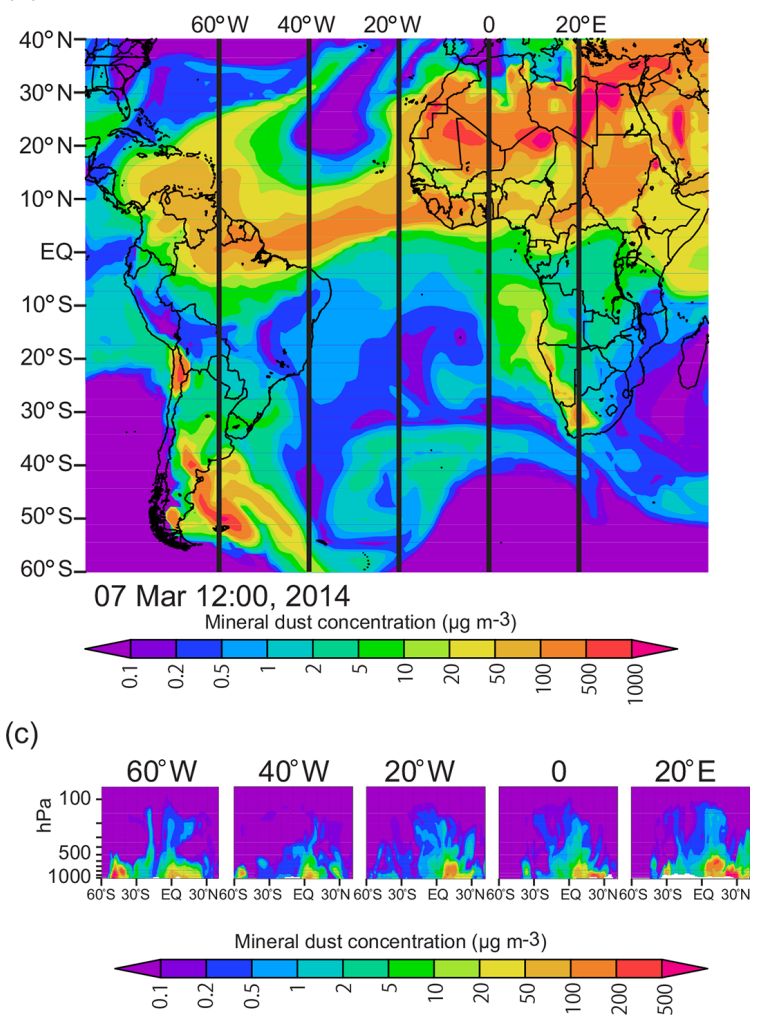

Figure 4. Model simulations of snapshots of (a) horizontal distributions of mineral dust concentrations at the surface level for each LRT period and (b) horizontal and (c) vertical distributions in a specific LRT event (7 March 2014). The sub-panels in (c) show the vertical distributions of mineral dust concentrations along the lines of longitude (black lines) in (b). All times given in Fig. 4 are in coordinated universal time (UTC).

Zuloaga et al., 2018; Rizzolo et al., 2017). More than half of the mineral particles are within this $\mathrm{Si} / \mathrm{Al}$ range, and their possible source is the Saharan desert judging from our and other model studies (e.g., Moran-Zuloaga et al., 2018). On the other hand, the average ratios of $\mathrm{Si} / \mathrm{Al}$ in several nonLRT samples (e.g., the sample from 26 March, 16:11 AMT; all TEM sampling times are in Amazon time) are lower than those in the LRT samples (Fig. 7). This result suggests that the mineralogy and compositions of mineral particles are different between LRT and other periods and that the latter can have local sources around the sampling site (e.g., farm and road).

Over half of the mineral particles have Na-bearing particles such as $\mathrm{NaCl}, \mathrm{Na}_{2} \mathrm{SO}_{4}$, and their mixtures on their surfaces. The weight percent values of $\mathrm{Na}-\mathrm{Cl}$ and $\mathrm{Na}-\mathrm{Mg}$ in the mineral particles show a positive correlation (Fig. 7), and $\sim 26 \%$ of mineral particles from all samples are internally mixed with sea-salt components. The values of $\mathrm{Cl} / \mathrm{Na}$ are lower than those in $\mathrm{NaCl}(\mathrm{Cl} / \mathrm{Na} \sim 1.5)$ because some $\mathrm{Cl}$ was replaced by sulfate, forming $\mathrm{Na}_{2} \mathrm{SO}_{4}$. LRT samples have higher $\mathrm{Na}, \mathrm{Cl}$, and $\mathrm{Mg}$ fractions than other samples (Fig. 7), suggesting that the LRT particles were mixed with sea salt during transport, possibly when traveling near the surface of the Atlantic Ocean (Fig. 4). Lidar measurements observed similar LRT of dust and biomass burning from Africa in the lowermost $2 \mathrm{~km}$ of the atmosphere during the AMAZE-2008 campaign (Baars et al., 2012). Such mixing of mineral and sea salt in the Amazon basin is consistent with studies using particle-induced X-ray emission (PIXE) for filter bulk measurements (Artaxo et al., 1990) or an electron probe microanalyzer and a scanning electron microscope for individual particle measurements (e.g., Worobiec et al., 2007; Wu et al., 2019), and we show here that sea salt occurs on the mineral particles as grains several hundred nanometers in size (Figs. 6 and S6).

\subsubsection{Primary biological aerosol (PBA) particles}

PBA particles are important in the Amazon basin because of their abundance and contributions to the regional climate and weather (Martin et al., 2010b; Pöschl et al., 2010). These particles include fungal spores, pollen, bacteria, algae, protozoa, and fragments of plants and organisms (Després et al., 2012; Li et al., 2020) and are known sources of K, Na, P, Cl, and $\mathrm{Fe}$ in the Amazon basin (Artaxo et al., 1993; Krejci et al., 2005; Wu et al., 2019). Biological sources in the Ama- 
(a) Size distributions

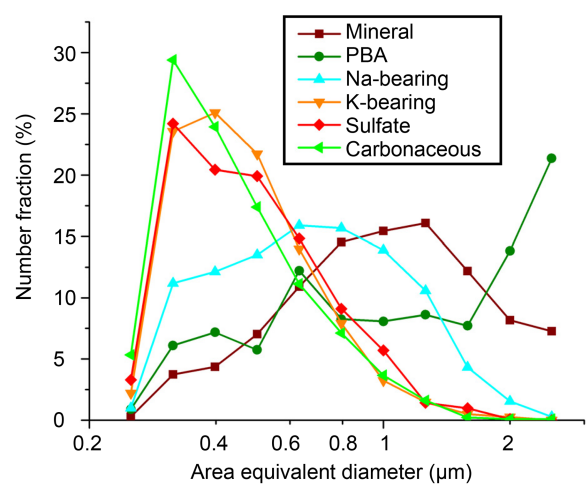

(b) Number fractions for LRT periods

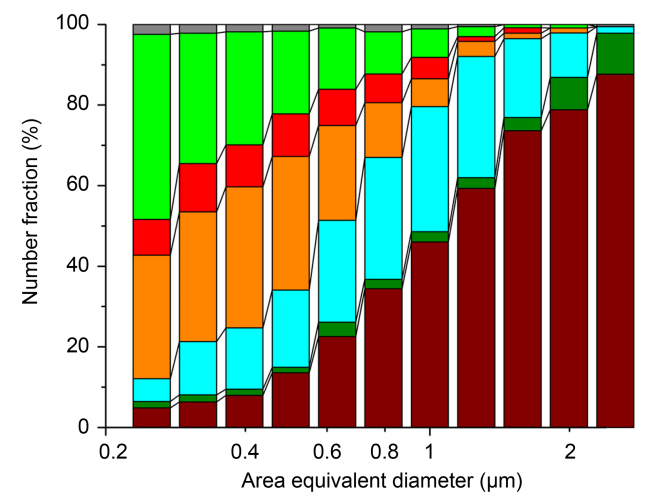

(c) Number fractions for other periods

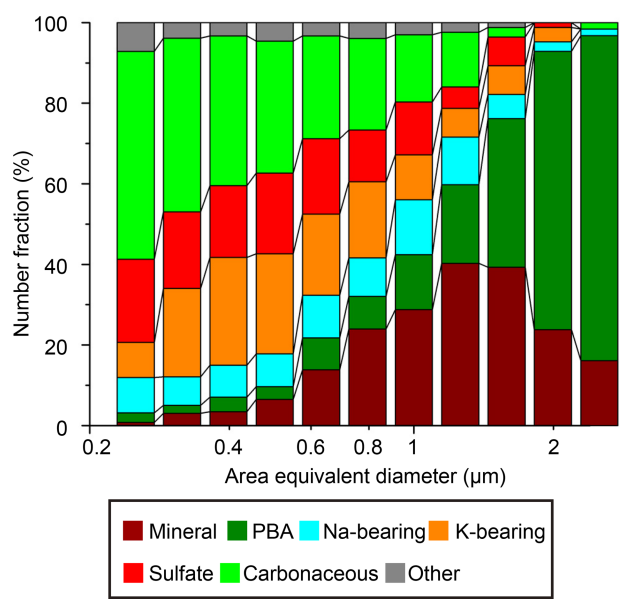

Figure 5. Size distributions and number fractions of each aerosol type. (a) Size distributions of each aerosol particle type among all samples. The $y$ axis shows the number fractions for each bin. Numbers are 2519 (mineral), 557 (PBA particles), 1806 (Na-bearing particles), 2223 (K-bearing particles), 1120 (sulfate), 2289 (carbonaceous particles), and 221 (other; not shown). Size-dependent number fractions of each aerosol particle type for (b) LRT periods and (c) other samples. Numbers are 7769 (LRT periods) and 2966 (other periods). Size bins are shown on a log scale, and the size ranges are less than $0.25,0.25-0.32,0.32-0.40,0.40-0.50,0.50-0.63,0.63$ $0.79,0.79-1.00,1.00-1.26,1.26-1.58,1.58-2.00$, and greater than $2.00 \mu \mathrm{m}$.
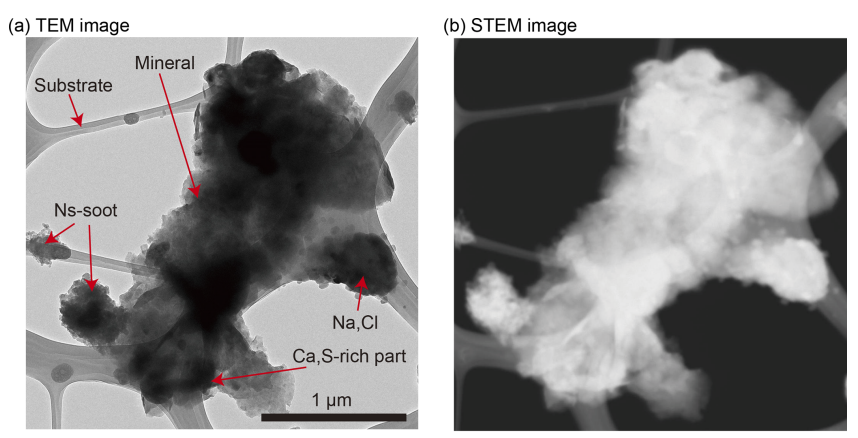

(c) Element mapping images
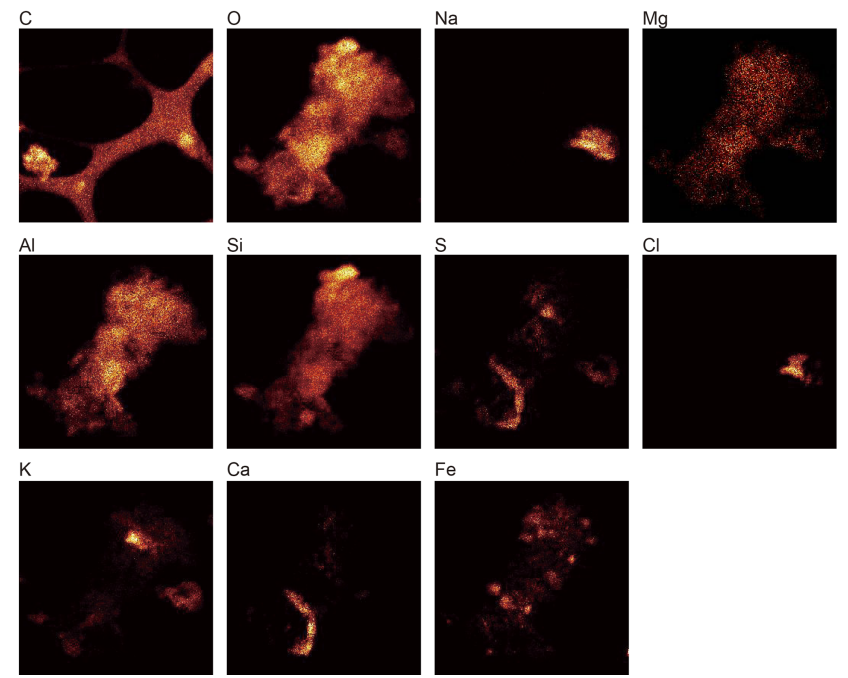

Figure 6. Shape and compositions of mineral particles. (a) TEM, (b) STEM, and (c) element mapping images of a mineral particle. This particle was obtained from the sample collected during 15:0015:30 on 2 March 2014 on a lacey carbon substrate.

zon can also emit $\mathrm{K}$ and $\mathrm{Na}$ salts as fine aerosol particles and influence new particle formation and cloud formation, respectively (China et al., 2016, 2018; Pöhlker et al., 2012), and act as INPs (Prenni et al., 2009).

PBA particles mainly consist of $\mathrm{C}$ and $\mathrm{O}$ and contain $\mathrm{P}, \mathrm{S}$, $\mathrm{N}, \mathrm{K}, \mathrm{Cl}$, and $\mathrm{Na}$ as minor components (Fig. 8). We used $\mathrm{P}$ as a tracer for PBA particles to distinguish them from other primary or secondary organic aerosol particles. Elemental distributions of PBA particles show that $\mathrm{P}$ occurs either uniformly within particles (Figs. 8; S3) or as phosphate (Fig. S4). PBA particle shapes depend on the types of biological sources (Fig. 9), although exact source identification requires measurements such as DNA analysis. The size distribution in the PBA particles has two peaks: $\sim 600 \mathrm{~nm}$ and greater than $2 \mu \mathrm{m}$ (Fig. 5). PBA particles greater than $2 \mu \mathrm{m}$ show unique shapes (Fig. 9), whereas small PBA particles can include fragmented fungal spores (China et al., 2016). The size distributions and shapes of large PBA particles are consistent with those described by Huffman et al. (2012) who measured PBA particles during the AMAZE-08 campaign. Relative number fractions of PBA particles are higher dur- 

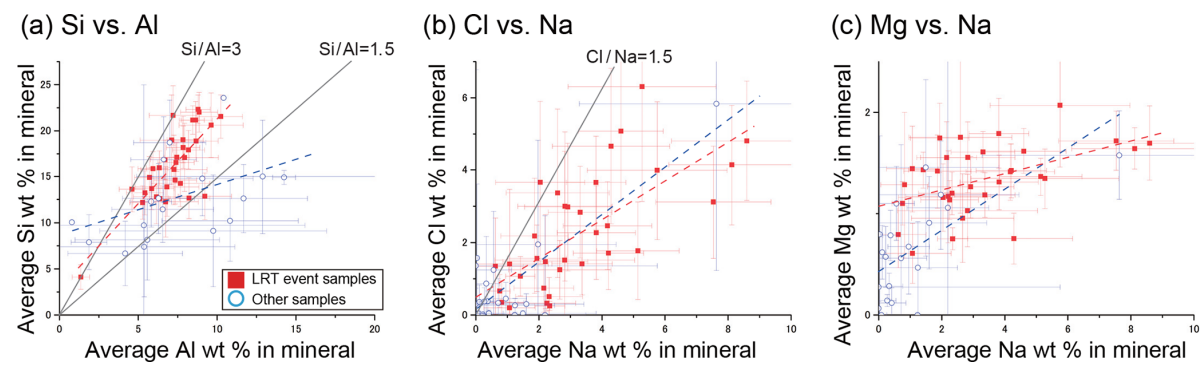

Figure 7. Relations (a) between average $\mathrm{Si}$ and $\mathrm{Al}$ weight percent in mineral particles, (b) between average $\mathrm{Cl}$ and $\mathrm{Na}$ weight percent in mineral particles, and (c) between average $\mathrm{Mg}$ and $\mathrm{Na}$ weight percent in mineral particles. Red squares indicate sample averaged values for LRT period samples. Open blue circles indicate sample average values for other (non-LRT period) samples. The sample from 09:00 on 6 February had only one mineral particle and is not shown in the plots because it has a large $\mathrm{Al}$ fraction and no $\mathrm{Na}(0,30$, and $1 \mathrm{wt} \%$ for $\mathrm{Na}$, $\mathrm{Al}$, and $\mathrm{Si}$, respectively). Coefficients of $R^{2}$ of determination for (a), (b), and (c) were $0.60,0.47$, and 0.24 for the LRT period samples and $0.18,0.66$, and 0.40 for other samples, respectively. Trend lines are shown in red and broken blue lines for LRT period and other samples, respectively. The correlation between $\mathrm{Si}$ and $\mathrm{Al}$ for other samples (a) is relatively low because of possible contributions from two sources (LRT and local dusts). Error bars indicate the $95 \%$ confidence intervals.

ing non-LRT periods than LRT periods (Fig. 2), given that they are emitted within the basin. PBA number fractions also show diurnal changes; i.e., they are high during the night (03:00) and low during the day (15:00) (Fig. 8). The number fractions of PBA particles during the night can be enhanced by high relative humidity $(\mathrm{RH})$, which increases active PBA particle emissions from plants, wind speed, and temperatures (Li et al., 2020; Elbert et al., 2007; Graham et al., 2003; Huffman et al., 2012; Whitehead et al., 2016). Various PBA particles are mixed with other materials such as minerals, sulfate, Na-bearing particles, or ns-soot (Figs. 8 and S5). For example, PBA particles in Figs. 8 and S5 attach ns-soot, and those in Fig. S3 attach a mineral particle. The number fractions of internally mixed PBA particles with sea salt are approximately $20 \%$ (Fig. 10). Na occurs on the PBA particle surface as a coating (Fig. S10) or as a particle constituent (Fig. 8).

\subsubsection{Sea-salt particles}

Sea-salt particles are emitted from the ocean and act as efficient cloud-condensation nuclei ( $\mathrm{CCN}) . \mathrm{Na}, \mathrm{Mg}$, and $\mathrm{Cl}$ are commonly used tracers of sea-salt particles, although $\mathrm{Cl}$ can be replaced by sulfate and nitrate in the atmosphere (Adachi and Buseck, 2015; Gard et al., 1998; Yoshizue et al., 2019). In this study, although the sampling site is far from the ocean (>1000 km), we commonly observed sea-salt particles and their mixtures with mineral particles (Figs. 6 and S6), sulfate (Fig. 11), and PBA particles (Fig. S10). Na-bearing particles, which include both marine and biological sources, have a broad size distribution with a mode size of $\sim 600 \mathrm{~nm}$ (Fig. 5). Number fractions of Na-bearing particles are more abundant during LRT periods than in other periods (Fig. 2). The deformed shapes of Na-bearing particles on the substrate suggest that they were hydrated in the atmosphere and on the substrates when collected (Fig. 11).
The weight percent ratios among $\mathrm{Na}$ and $\mathrm{Mg}$ within $\mathrm{Na}$ bearing particles show that more than $70 \%$ is sea salt that has a $\mathrm{Mg} / \mathrm{Na}$ weight percent between 0.05 and 0.3 (Fig. 10). Some remaining particles can be sea salt because the $\mathrm{Mg}$ weight percent is lower than the detection limit $(\sim 0.1 \mathrm{wt} \%)$ within the Na-bearing particles having a relatively low $\mathrm{Na}$ weight percent. A stoichiometry calculation using $\mathrm{S}$ and $\mathrm{Cl}$ weight percent indicates that $\sim 74 \%$ in mole fractions of $\mathrm{Cl}$ was replaced with sulfate. Nitrate can also react with $\mathrm{NaCl}$ and form sodium nitrate. However, we did not observe it in this study because of lower concentrations of nitrate than sulfate during the campaign (de Sá et al., 2018) and insensitivity of nitrate detection in the current TEM analysis. Internally mixed sea-salt fractions are higher in samples from LRT periods than those in other periods (Fig. 10c).

\subsubsection{K-bearing particles}

Potassium is one of the key elements in the Amazon basin that acts as a seed to form secondary organic aerosol particles (Pöhlker et al., 2012). Potassium-bearing particles have a modal peak at $400 \mathrm{~nm}$, and their number fractions are similar between LRT periods and other periods (Fig. 5). Many Kbearing particles consist of inorganic salts and include $\mathrm{S}$ as sulfate (Fig. S7), C as ns-soot or organic matter (Fig. S7), Cl as chloride (Fig. S5), or their mixtures. In addition, K occurs in mineral dust particles (Figs. 6 and S2) and PBA (Figs. S3 and S4) as a minor component. Potassium is a common constituent of mineral dust such as K-feldspar and an essential component of biological species and was detected in $\sim 80 \%$ of all our analyzed particles, mostly as minor fractions.

Pöhlker et al. (2012) found K in nearly all particles and observed that the K mass fraction increased for smaller particles in samples collected at the ATTO site, which has a negligible influence from Manaus. The authors suggested that the $\mathrm{K}$ was from biogenic sources but not biomass burning be- 
(a) TEM image

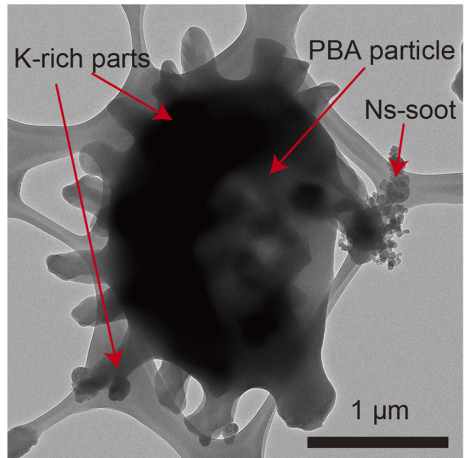

(c) Element mapping images

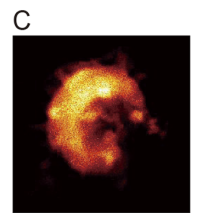

$\mathrm{Na}$

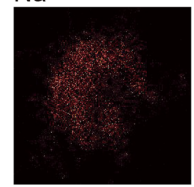

$\mathrm{Cl}$

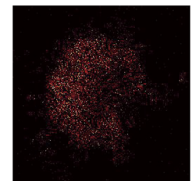

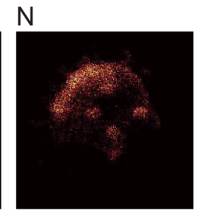

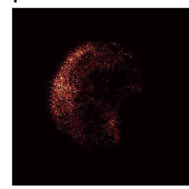

$\mathrm{K}$

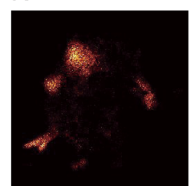

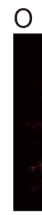

$S$

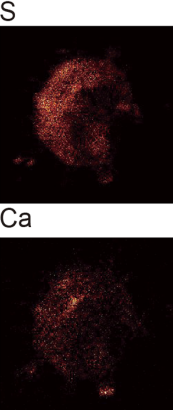

(b) STEM image

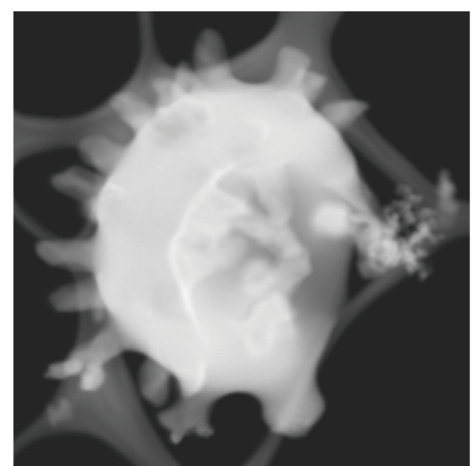

(d) Diurnal number fraction

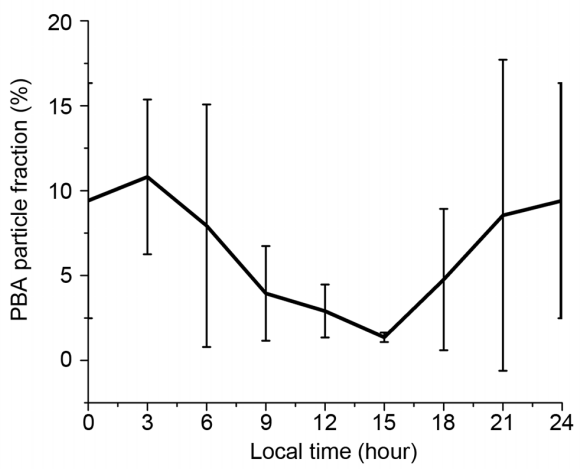

Figure 8. Shape, compositions, and diurnal abundance of PBA particles. (a) TEM, (b) STEM, and (c) element mapping images of a PBA particle. This particle contains K-rich and C-N-O-rich grains and attaches an ns-soot particle. The sample was collected from 00:00 to 00:30 on 27 February 2014. (d) Diurnal number fractions of PBA particles. The fractions were averaged values for all samples. Error bars indicate the $95 \%$ confidence intervals.

cause of a lack of ns-soot particles. In contrast, our samples include K-bearing particles with ns-soot particles (Fig. S7), and the mixing state is similar to that in biomass burning ( $\mathrm{Li}$ et al., 2003; Wu et al., 2019; Yokelson et al., 2007). Thus, although there were few wildfires during the wet season, biomass burning from LRT, local biofuel burning, and other anthropogenic sources can contribute to our K-bearing particles collected at the T3 site.

\subsubsection{Sulfate}

Nearly $10 \%$ of all particles are classified as sulfate (Fig. 2), although $\mathrm{S}$ was detected in $\sim 90 \%$ of all analyzed particles as a minor component of mineral, PBA, and $\mathrm{Na}$ - and $\mathrm{K}$ bearing particles. The size distribution of sulfate has a modal peak at $\sim 400 \mathrm{~nm}$ (Fig. 5). Nearly $80 \%$ of sulfate particles include $\mathrm{N}, \mathrm{K}(<2 \mathrm{wt} \%)$, or both, suggesting that they are mostly ammonium or potassium sulfate (Fig. S8). Anthropogenic pollutants including sulfate from Manaus were spo- radically transported to the T3 site (de Sá et al., 2017). For example, during the period that was classified as having polluted conditions from Manaus (de Sá et al., 2018), the TEM samples had approximately three times higher sulfate number fractions than those from background periods (Fig. 2). Sulfate in the Amazon can be formed by the reactions of $\mathrm{SO}_{2}$, dimethyl sulfide (DMS), $\mathrm{H}_{2} \mathrm{~S}$, or $\mathrm{CS}_{2}$ emitted from local sources (e.g., plants, microorganisms, and anthropogenic emissions) and LRT sources (e.g., biomass burning and anthropogenic emissions from Africa and the Atlantic Ocean) (Martin et al., 2010b).

\subsubsection{Carbonaceous particles}

Carbonaceous particles include secondary or primary organic aerosol (SOA and POA, respectively), tarball, and ns-soot particles (Fig. S9). The vapor pressure of volatile and semivolatile organic compounds was too high to retain them in the particles after sampling and during the TEM analysis, re- 

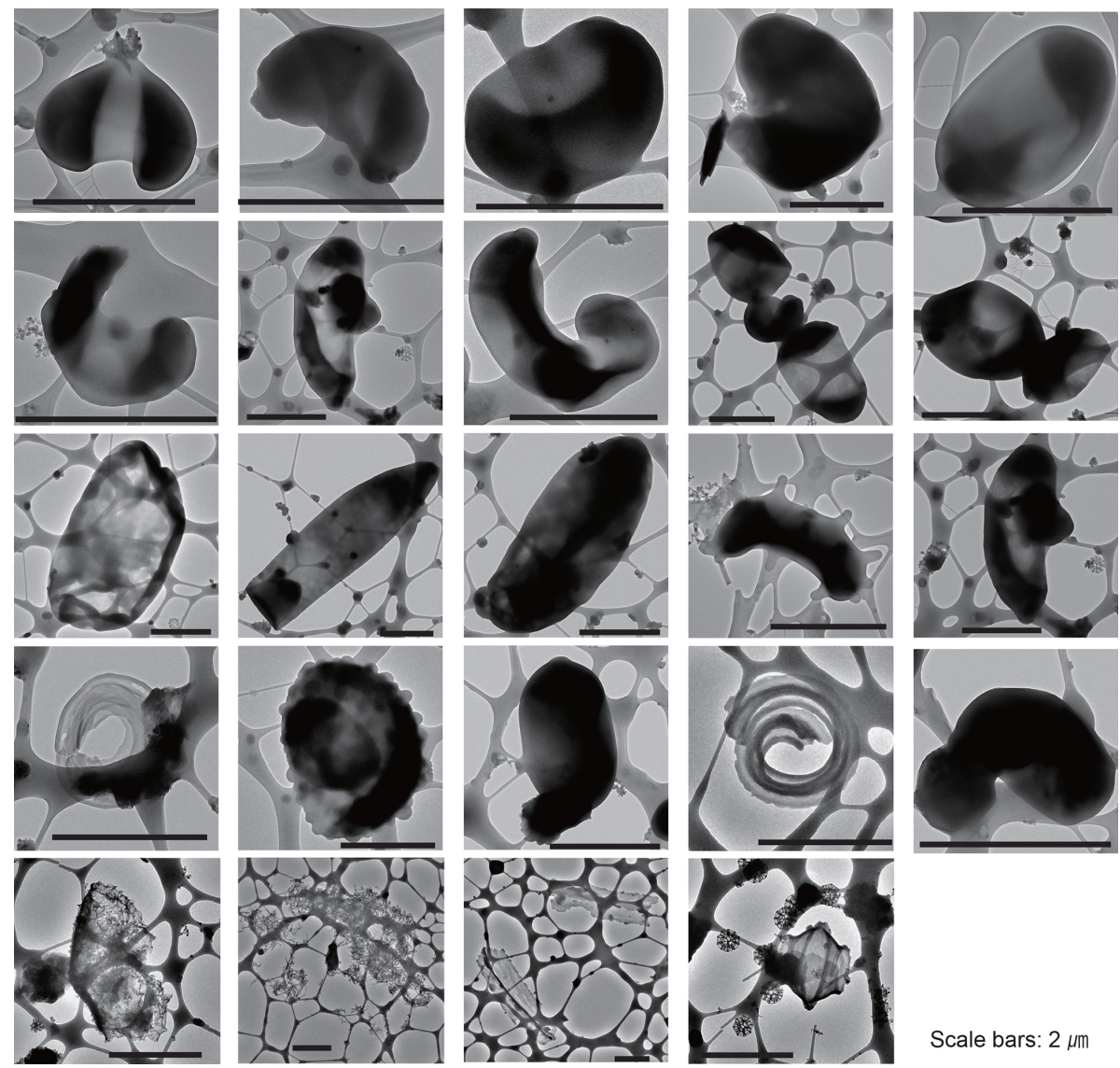

Scale bars: $2 \mu \mathrm{m}$

Figure 9. Examples of TEM images of PBA and the relevant particles. The TEM images were obtained from samples collected during other (background) periods (09:00, 7 February; 15:00, 10 February; 00:00, 27 February; 03:00, 15 March 2014; 09:00, 18 March 2014). Brochosome particles, which originate from leafhoppers (Wittmaack, 2005), were abundant in some samples (e.g., bottom right image) and were included in the "other" category because they do not contain P. Some particles were too fragile to analyze the composition (e.g., three images from the bottom left), although their shapes imply that they have biological sources. As these PBA particles were observed under vacuum, they can have inflated shapes when observed in ambient conditions.

(a) Mineral particles

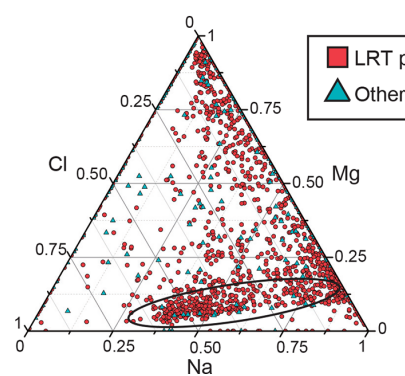

(b) PBA particles

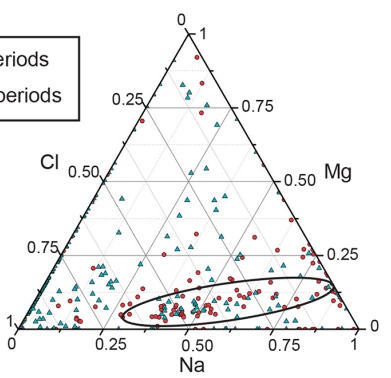

(c) Na-bearing particles

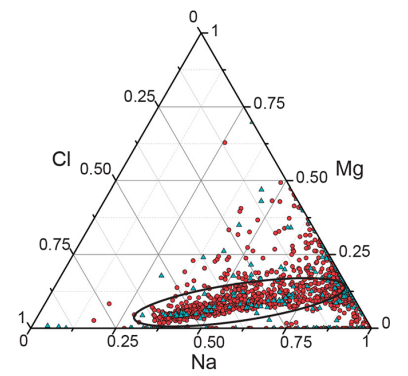

Figure 10. Weight percent ratios among $\mathrm{Na}, \mathrm{Mg}$, and $\mathrm{Cl}$ within (a) mineral particles, (b) PBA particles, and (c) Na-bearing particles. The black elliptical areas indicate typical sea-salt compositions from a marine source.

sulting in the loss of the volatile fraction from the particles collected on the TEM grids. Thus, the carbonaceous particle fractions can be underestimated, and we focus only on the nonvolatile fractions.
Carbonaceous particles have higher fractions at smaller sizes for both the LRT period and other samples (Fig. 5). SOA particles are organic particles having round shapes with a deformation on the substrate when collected (e.g., Fig. 11). These particles form through the oxidation of low-volatile 
(a) TEM image

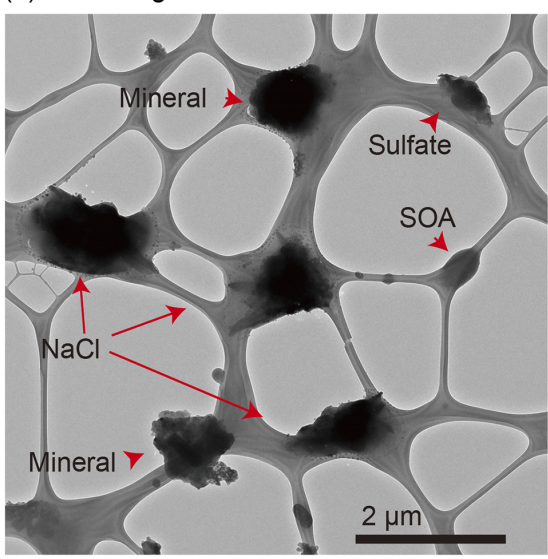

(c) Element mapping images
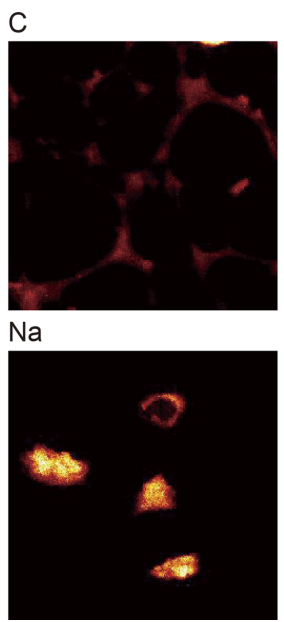

$\mathrm{Mg}$

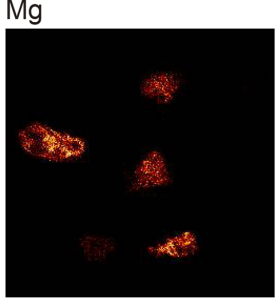

$S$

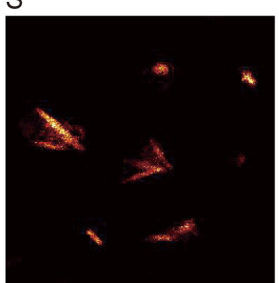

(b) STEM image

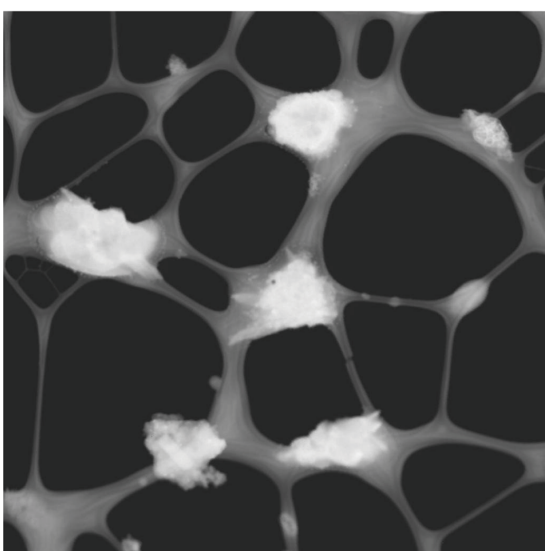

Al

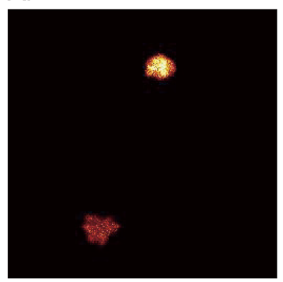

$\mathrm{Cl}$

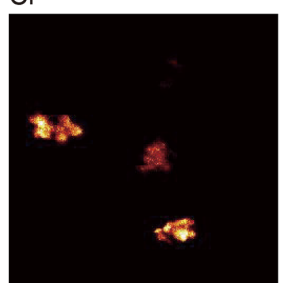

$\mathrm{Si}$

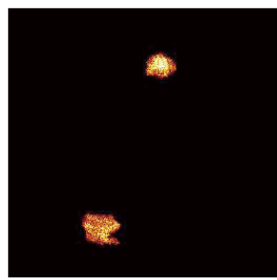

$\mathrm{Ca}$

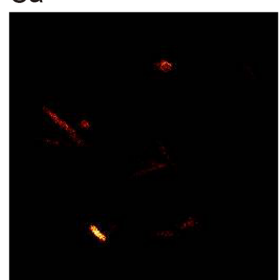

Figure 11. Shapes and compositions of sea-salt particles. (a) TEM, (b) STEM, and (c) element mapping images of sea-salt and mineral particles. These sea-salt particles also contain $\mathrm{S}$ as sulfate. The sample was collected from 12:00 to 12:30 on 2 February 2014.

organic matter emitted from both natural and anthropogenic sources (de Sá et al., 2018). Wang et al. (2016a) showed that small particles are transported from the free troposphere into the boundary layer by vertical transports during precipitation events, and such particles can be nuclei of the SOA particles in the background condition. Tarballs originate from biomass burning and have an amorphous structure and spherical shapes on the substrate (Adachi et al., 2019), and their number fractions are less than $1 \%$ in our samples. Ns-soot particles that are internally mixed with K-bearing particles can originate from LRT (Saturno et al., 2018) or local biofuel burning for cooking or brick kilns (Martin et al., 2016). Other ns-soot particles can be from anthropogenic sources such as Manaus and neighboring cities (Glicker et al., 2019). Ns-soot particles are attached to or embedded within the mineral, sulfate, organic, Na- and K-bearing, and PBA particles (Figs. 6, 8, S2, S5, and S7). As ns-soot particles absorb light, they can change the optical properties of these mixed particles into more light-absorbing particles.

\subsection{Possible mixing processes and implications for the climate}

Number fractions of aerosol particle types as a function of size largely differ between the LRT period and other samples (Fig. 5). The size-dependent number fractions of samples from other periods are roughly consistent with the results during the AMAZE-08 campaign (Pöschl et al., 2010). At large particle sizes $(>2 \mu \mathrm{m})$, mineral and PBA particles are dominant during LRT and other periods, respectively, whereas carbonaceous particles dominate in fine particles for both periods. During the LRT periods, most mineral and biomass burning particles such as K-bearing and ns-soot particles could originate from the African continent, and the seasalt particles came from the Atlantic Ocean. We assume that these particles were coagulated or condensed during transport (Fig. 12).

Many Na-bearing particles are internally mixed with mineral and PBA particles (Fig. S6) or on the surfaces of bio- 


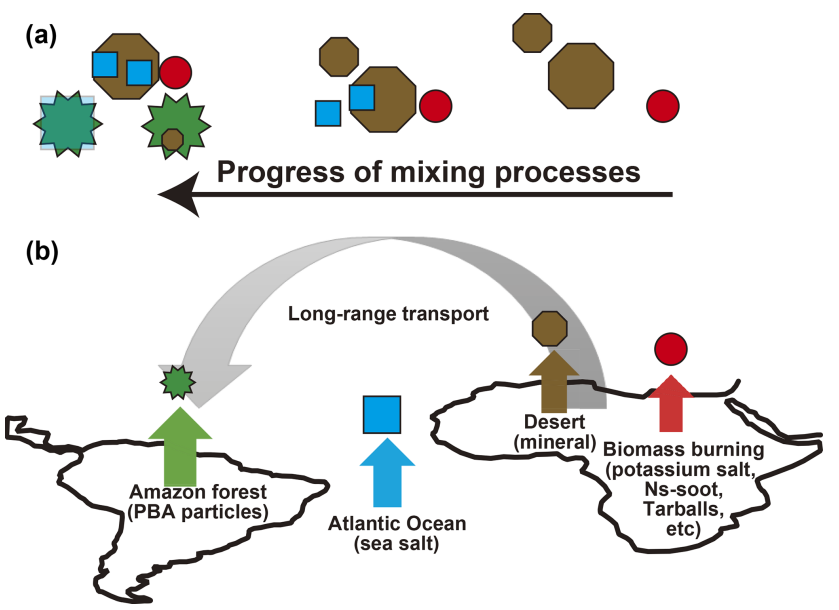

Figure 12. Schematic image of possible particle sources and transport pathways. Panel (a) shows the progress of individual particle mixing during LRT. Panel (b) shows possible major sources for each particle (Martin et al., 2010b).

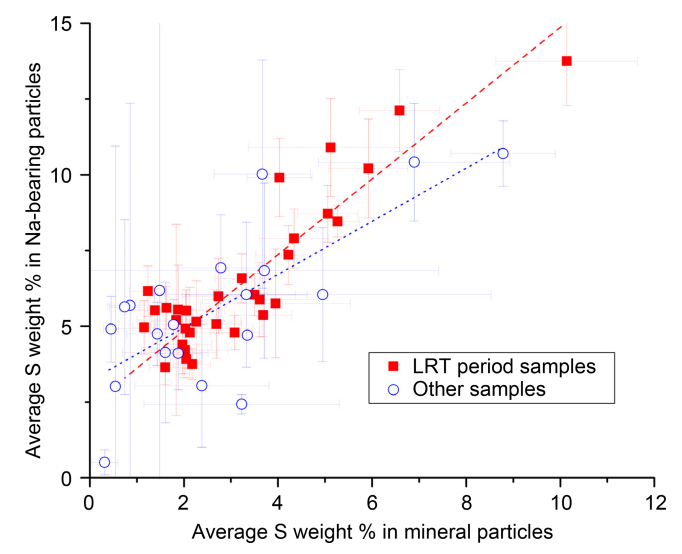

Figure 13. The relation between average $S$ weight percent in seasalt and mineral particles within LRT periods (open red squares) and other (blue circles) samples. Coefficients of $R^{2}$ of determination were 0.80 and 0.51 for the LRT period (red dashed line) and other samples (blue dotted line), respectively.

logical particles (Fig. S10). In the LRT samples, more than $20 \%$ of the mineral and PBA particles contain sea salt. Sulfate particles are commonly coagulated or condensed with other aerosol components to form various internal mixtures. We found correlations of sample average weight percent of $\mathrm{S}$ between Na-bearing and mineral particles (Fig. 13). The results suggest that mixing with sulfate occurred during LRT over the Atlantic Ocean and above the Amazon basin rather than at their source regions (Fig. 12).

In the Amazon forest, the RH commonly exceeds more than $80 \%$ during the night. The mixing states of mineral and PBA particles suggest that hygroscopic particles such as $\mathrm{NaCl}$ and $\left(\mathrm{NH}_{4}\right)_{2} \mathrm{SO}_{4}$ deliquesce on the surface of these host particles under high-RH conditions, and thus they increase their sizes by absorbing water.

The detailed mixing states of individual particles are important to understand their contributions to the climate. In our samples, most particles consist of several components from sources such as the Amazon forest, Saharan desert, Atlantic Ocean, and African biomass burning, some of which are separated by thousands of kilometers (Fig. 12). Although such complex mixing states are common for anthropogenic aerosol particles (e.g., Ching et al., 2019), we found that particles from natural sources can also be mixed during LRT and form internally mixed particles, resulting in different hygroscopicity and optical properties.

\section{Conclusions}

The compositions and mixing states of individual particles from natural sources in the Amazon basin are important for understanding their roles in cloud formation and radiative forcing, as well as for transport and removal processes. It is difficult to evaluate the compositions and mixing states of refractory particles using online instruments. In contrast, the TEM results show that primary particles, including minerals, sea salt, and PBA, dominate in the fine-mode particles during the wet season, and their number fractions vary depending on whether they originate from LRT or local sources. This study shows the mixing states of these particles, focusing on the occurrences of individual components on particles, with sizes ranging from hundreds of nanometers to several micrometers. Sea-salt and sulfate particles commonly occur on the surfaces of mineral and PBA particles. As the LRT particles have more processed mixed particles than other background particles, we interpret that the mixing mainly occurred during the LRT through coagulation, condensation, or both. The element mapping images also showed that $\mathrm{K}$ and $\mathrm{Na}$ occurred either as attached inorganic salts or as constituents of PBA and mineral particles. Our model simulation suggests that mineral particles during LRT periods originated from the Saharan desert. Although mineral particles are originally hydrophobic, the LRT mineral particles can become hygroscopic by mixing with sea-salt and sulfate particles.

This study focuses on individual particles from samples collected during the wet season in the Amazon basin. Many particles are internally mixed with other components and can have different hygroscopicity and optical properties from their original sources and/or states. Although previous studies suggested possible local biological sources for $\mathrm{K}$ and $\mathrm{Na}$, our observations show that they could originate from both LRT and local sources. We conclude that many primary particles from natural sources become internally mixed and change compositions while traveling across long distances and various environments. When mineral particles or other hydrophilic primary particles are mixed with sea salt or sulfate, they can absorb water efficiently, resulting in increasing 
$\mathrm{CCN}$ activity, changing the optical properties, and accelerating their removal from the atmosphere, all of which should be taken into account when considering their actual occurrence in the atmosphere to evaluate their climate influences.

Code and data availability. The data sets used in this publication are available at the ARM Climate Research Facility database for the GoAmazon2014/5 experiment (https://www.arm.gov/research/ campaigns/amf2014goamazon; GoAmazon Science Team, 2020). The TEM data and the simulation data used in this publication are available upon request (adachik@mri-jma.go.jp). Access to the MRI-ESM2 code is available under a collaboration framework with MRI.

Supplement. The supplement related to this article is available online at: https://doi.org/10.5194/acp-20-11923-2020-supplement.

Author contributions. KA and PRB planned the TEM experiments. KA carried out the TEM analyses and data processing. KA, ZG, SdS, APB, JFdB, GGC, and AJS III carried out the TEM sampling and field observations. STM and PA supervised the GoAmazon2014/5 campaign and TEM sampling. NO performed the simulations. KA prepared the paper with contributions from all coauthors.

Competing interests. The authors declare that they have no conflict of interest.

Special issue statement. This article is part of the special issue "Observations and Modeling of the Green Ocean Amazon (GoAmazon2014/5) (ACP/AMT/GI/GMD inter-journal SI)". It is not associated with a conference.

Acknowledgements. Kouji Adachi and Naga Oshima thank the support of the Environment Research and Technology Development Fund (JPMEERF20165005, JPMEERF20172003, JPMEERF20202003, and JPMEERF20205001) of the Environmental Restoration and Conservation Agency of Japan, the Global Environmental Research Coordination System from the Ministry of the Environment, Japan, and the Japan Society for the Promotion of Science (JSPS) KAKENHI (grant numbers JP25740008, JP26701004, JP16K16188, 16H01772, JP18H04134, JP18H03363, JP19H01972, JP19H04236, JP19K21905, and JP19H04259). Institutional support was provided by the Central Office of the Large Scale Biosphere Atmosphere Experiment in Amazonia (LBA), the National Institute of Amazonian Research (INPA), and Amazonas State University (UEA). We acknowledge the Atmospheric Radiation Measurement (ARM) Climate Research Facility, a user facility of the United States Department of Energy, Office of Science, sponsored by the Office of Biological and Environmental Research, and support from the Atmospheric System Research (ASR) program of that office. The research was conducted under scientific licenses
001030/2012-4, 001262/2012-2, and 00254/2013-9 of the Brazilian National Council for Scientific and Technological Development $(\mathrm{CNPq})$. We acknowledge the use of imagery from the NASA Worldview application (https://worldview.earthdata.nasa.gov, last access: 20 October 2020), part of the NASA Earth Observing System Data and Information System (EOSDIS).

Financial support. This research has been supported by the Environment Research and Technology Development Fund (grant nos. JPMEERF20165005, JPMEERF20172003, JPMEERF20202003, and JPMEERF20205001), the Global Environmental Research Coordination System, and the JSPS KAKENHI (grant nos. JP25740008, JP26701004, JP16K16188, JP16H01772, JP18H04134， JP18H03363， JP19H01972， JP19H04236, JP19K21905, and JP19H04259).

Review statement. This paper was edited by Tuukka Petäjä and reviewed by two anonymous referees.

\section{References}

Adachi, K. and Buseck, P. R.: Internally mixed soot, sulfates, and organic matter in aerosol particles from Mexico City, Atmos. Chem. Phys., 8, 6469-6481, https://doi.org/10.5194/acp-8-64692008, 2008.

Adachi, K. and Buseck, P. R.: Changes in shape and composition of sea-salt particles upon aging in an urban atmosphere, Atmos. Environ., 100, 1-9, https://doi.org/10.1016/j.atmosenv.2014.10.036, 2015.

Adachi, K., Chung, S. H., and Buseck, P. R.: Shapes of soot aerosol particles and implications for their effects on climate, J. Geophys. Res., 115, D15206, https://doi.org/10.1029/2009jd012868, 2010.

Adachi, K., Freney, E. J., and Buseck, P. R.: Shapes of internally mixed hygroscopic aerosol particles after deliquescence, and their effect on light scattering, Geophys. Res. Lett., 38, L13804, https://doi.org/10.1029/2011gl047540, 2011.

Adachi, K., Sedlacek, A. J., Kleinman, L., Chand, D., Hubbe, J. M., and Buseck, P. R.: Volume changes upon heating of aerosol particles from biomass burning using transmission electron microscopy, Aerosol Sci. Tech., 52, 46-56, https://doi.org/10.1080/02786826.2017.1373181, 2018.

Adachi, K., Sedlacek, A. J., III, Kleinman, L., Springston, S. R., Wang, J., Chand, D., Hubbe, J. M., Shilling, J. E., Onasch, T. B., Kinase, T., Sakata, K., Takahashi, Y., and Buseck, P. R.: Spherical tarball particles form through rapid chemical and physical changes of organic matter in biomassburning smoke, P. Natl. Acad. Sci. USA, 116, 19336-19341, https://doi.org/10.1073/pnas.1900129116, 2019.

Andreae, M. O.: Aerosols before pollution, Science, 315, 50-51, https://doi.org/10.1126/science.1136529, 2007.

Andreae, M. O., Acevedo, O. C., Araùjo, A., Artaxo, P., Barbosa, C. G. G., Barbosa, H. M. J., Brito, J., Carbone, S., Chi, X., Cintra, B. B. L., da Silva, N. F., Dias, N. L., Dias-Júnior, C. Q., Ditas, F., Ditz, R., Godoi, A. F. L., Godoi, R. H. M., Heimann, M., Hoffmann, T., Kesselmeier, J., Könemann, T., Krüger, M. L., Lavric, J. V., Manzi, A. O., Lopes, A. P., Martins, D. L., Mikhailov, E. 
F., Moran-Zuloaga, D., Nelson, B. W., Nölscher, A. C., Santos Nogueira, D., Piedade, M. T. F., Pöhlker, C., Pöschl, U., Quesada, C. A., Rizzo, L. V., Ro, C.-U., Ruckteschler, N., Sá, L. D. A., de Oliveira Sá, M., Sales, C. B., dos Santos, R. M. N., Saturno, J., Schöngart, J., Sörgel, M., de Souza, C. M., de Souza, R. A. F., Su, H., Targhetta, N., Tóta, J., Trebs, I., Trumbore, S., van Eijck, A., Walter, D., Wang, Z., Weber, B., Williams, J., Winderlich, J., Wittmann, F., Wolff, S., and Yáñez-Serrano, A. M.: The Amazon Tall Tower Observatory (ATTO): overview of pilot measurements on ecosystem ecology, meteorology, trace gases, and aerosols, Atmos. Chem. Phys., 15, 10723-10776, https://doi.org/10.5194/acp-15-10723-2015, 2015.

Artaxo, P. and Hansson, H. C.: Size distribution of biogenic aerosol particles from the amazon basin, Atmos. Environ., 29, 393-402, 1995.

Artaxo, P., Maenhaut, W., Storms, H., and Van Grieken, R.: Aerosol characteristics and sources for the Amazon Basin during the wet season, J. Geophys. Res., 95, 16971-16985, https://doi.org/10.1029/JD095iD10p16971, 1990.

Artaxo, P., Gerab, F., and Rabello, M. L. C.: Elemental composition of aerosol particles from two atmospheric monitoring stations in the Amazon Basin, Nucl. Instrum. Meth. B, 75, 277-281, 1993.

Artaxo, P., Martins, J. V., Yamasoe, M. A., Procópio, A. S., Pauliquevis, T. M., Andreae, M. O., Guyon, P., Gatti, L. V., and Leal, A. M. C.: Physical and chemical properties of aerosols in the wet and dry seasons in Rondônia, Amazonia, J. Geophys. Res., 107, 8081, https://doi.org/10.1029/2001JD000666, 2002.

Baars, H., Ansmann, A., Althausen, D., Engelmann, R., Heese, B., Müller, D., Artaxo, P., Paixao, M., Pauliquevis, T., and Souza R.: Aerosol profiling with lidar in the Amazon Basin during the wet and dry season, J. Geophys. Res., 117, D21201, https://doi.org/10.1029/2012JD018338, 2012.

Bateman, A. P., Gong, Z., Liu, P., Sato, B., Cirino, G., Zhang, Y., Artaxo, P., Bertram, A. K., Manzi, A. O., Rizzo, L. V., Souza, R. A. F., Zaveri, R. A., and Martin, S. T.: Sub-micrometre particulate matter is primarily in liquid form over Amazon rainforest, Nat. Geosci., 9, 34-37, https://doi.org/10.1038/ngeo2599, 2015.

Bateman, A. P., Gong, Z., Harder, T. H., de Sá, S. S., Wang, B., Castillo, P., China, S., Liu, Y., O’Brien, R. E., Palm, B. B., Shiu, H.-W., Cirino, G. G., Thalman, R., Adachi, K., Alexander, M. L., Artaxo, P., Bertram, A. K., Buseck, P. R., Gilles, M. K., Jimenez, J. L., Laskin, A., Manzi, A. O., Sedlacek, A., Souza, R. A. F., Wang, J., Zaveri, R., and Martin, S. T.: Anthropogenic influences on the physical state of submicron particulate matter over a tropical forest, Atmos. Chem. Phys., 17, 1759-1773, https://doi.org/10.5194/acp-17-1759-2017, 2017.

Brito, J., Rizzo, L. V., Morgan, W. T., Coe, H., Johnson, B., Haywood, J., Longo, K., Freitas, S., Andreae, M. O., and Artaxo, P.: Ground-based aerosol characterization during the South American Biomass Burning Analysis (SAMBBA) field experiment, Atmos. Chem. Phys., 14, 12069-12083, https://doi.org/10.5194/acp-14-12069-2014, 2014.

Bristow, C. S., Hudson-Edwards, K. A., and Chappell, A.: Fertilizing the Amazon and equatorial Atlantic with West African dust, Geophys. Res. Lett., 37, L14807, https://doi.org/10.1029/2010g1043486, 2010.

Buseck, P. R., Adachi, K., Gelencsér, A., Tompa, É., and Pósfai, M.: Ns-Soot: A Material-Based Term for Strongly Light-
Absorbing Carbonaceous Particles, Aerosol Sci. Tech., 48, 777788, https://doi.org/10.1080/02786826.2014.919374, 2014.

Cappa, C. D., Onasch, T. B., Massoli, P., Worsnop, D. R., Bates, T. S., Cross, E. S., Davidovits, P., Hakala, J., Hayden, K. L., Jobson, B. T., Kolesar, K. R., Lack, D. A., Lerner, B. M., Li, S.-M., Mellon, D., Nuaaman, I., Olfert, J. S., Petäjä, T., Quinn, P. K., Song, C., Subramanian, R., Williams, E. J., and Zaveri, R. A.: Radiative Absorption Enhancements Due to the Mixing State of Atmospheric Black Carbon, Science, 337, 1078-1081, https://doi.org/10.1126/science.1223447, 2012.

Caquineau, S., Gaudichet, A., Gomes, L., Magonthier, M.-C., and Chatenet, B.: Saharan dust: Clay ratio as a relevant tracer to assess the origin of soil-derived aerosols, Geophys. Res. Lett., 25, 983-986, https://doi.org/10.1029/98gl00569, 1998.

Carslaw, K. S., Lee, L. A., Reddington, C. L., Pringle, K. J., Rap, A., Forster, P. M., Mann, G. W., Spracklen, D. V., Woodhouse, M., Regayre, L. A., and Pierce, J. R.: Large contribution of natural aerosols to uncertainty in indirect forcing, Nature, 503, 67-71, https://doi.org/10.1038/nature12674, 2013.

China, S., Wang, B., Weis, J., Rizzo, L., Brito, J., Cirino, G. G., Kovarik, L., Artaxo, P., Gilles, M. K., and Laskin, A.: Rupturing of Biological Spores As a Source of Secondary Particles in Amazonia, Environ. Sci. Technol., 50, 12179-12186, https://doi.org/10.1021/acs.est.6b02896, 2016.

China, S., Burrows, S. M., Wang, B., Harder, T. H., Weis, J., Tanarhte, M., Rizzo, L. V., Brito, J., Cirino, G. G., Ma, P. L., Cliff, J., Artaxo, P., Gilles, M. K., and Laskin, A.: Fungal spores as a source of sodium salt particles in the Amazon basin, Nat. Commun., 9, 4793, https://doi.org/10.1038/s41467-018-070664, 2018.

Ching, J., Adachi, K., Zaizen, Y., Igarashi, Y., and Kajino, M.: Aerosol mixing state revealed by transmission electron microscopy pertaining to cloud formation and human airway deposition, Climate and Atmospheric Science, 2, 22, https://doi.org/10.1038/s41612-019-0081-9, 2019.

Cirino, G., Brito, J., Barbosa, H. M. J., Rizzo, L. V., Tunved, P., de Sá, S. S., Jimenez, J. L., Palm, B. B., Carbone, S., Lavric, J. V., Souza, R. A. F., Wolff, S., Walter, D., Tota, J., Oliveira, M. B. L., Martin, S. T., and Artaxo, P.: Observations of Manaus urban plume evolution and interaction with biogenic emissions in GoAmazon 2014/5, Atmos. Environ., 191, 513-524, https://doi.org/10.1016/j.atmosenv.2018.08.031, 2018.

de Sá, S. S., Palm, B. B., Campuzano-Jost, P., Day, D. A., Hu, W., Isaacman-VanWertz, G., Yee, L. D., Brito, J., Carbone, S., Ribeiro, I. O., Cirino, G. G., Liu, Y., Thalman, R., Sedlacek, A., Funk, A., Schumacher, C., Shilling, J. E., Schneider, J., Artaxo, P., Goldstein, A. H., Souza, R. A. F., Wang, J., McKinney, K. A., Barbosa, H., Alexander, M. L., Jimenez, J. L., and Martin, S. T.: Urban influence on the concentration and composition of submicron particulate matter in central Amazonia, Atmos. Chem. Phys., 18, 12185-12206, https://doi.org/10.5194/acp-18-121852018, 2018.

de Sá, S. S., Palm, B. B., Campuzano-Jost, P., Day, D. A., Newburn, M. K., Hu, W., Isaacman-VanWertz, G., Yee, L. D., Thalman, R., Brito, J., Carbone, S., Artaxo, P., Goldstein, A. H., Manzi, A. O., Souza, R. A. F., Mei, F., Shilling, J. E., Springston, S. R., Wang, J., Surratt, J. D., Alexander, M. L., Jimenez, J. L., and Martin, S. T.: Influence of urban pollution on the production of organic particulate matter from isoprene epoxydi- 
ols in central Amazonia, Atmos. Chem. Phys., 17, 6611-6629, https://doi.org/10.5194/acp-17-6611-2017, 2017.

Després, V., Huffman, J. A., Burrows, S. M., Hoose, C., Safatov, A., Buryak, G., Fröhlich-Nowoisky, J., Elbert, W., Andreae, M., Pöschl, U., and Jaenicke, R.: Primary biological aerosol particles in the atmosphere: a review, Tellus B, 64, 15598, https://doi.org/10.3402/tellusb.v64i0.15598, 2012.

Elbert, W., Taylor, P. E., Andreae, M. O., and Pöschl, U.: Contribution of fungi to primary biogenic aerosols in the atmosphere: wet and dry discharged spores, carbohydrates, and inorganic ions, Atmos. Chem. Phys., 7, 4569-4588, https://doi.org/10.5194/acp-74569-2007, 2007.

Formenti, P., Andreae, M. O., Lange, L., Roberts, G., Cafmeyer, J., Rajta, I., Maenhaut, W., Holben, B. N., Artaxo, P., and Lelieveld, J.: Saharan dust in Brazil and Suriname during the Large-Scale Biosphere-Atmosphere Experiment in Amazonia (LBA) - Cooperative LBA Regional Experiment (CLAIRE) in March 1998, J. Geophys. Res.-Atmos., 106, 14919-14934, https://doi.org/10.1029/2000jd900827, 2001

Fraund, M., Pham, D., Bonanno, D., Harder, T., Wang, B., Brito, J., de Sá, S., Carbone, S., China, S., Artaxo, P., Martin, S., Pöhlker, C., Andreae, M., Laskin, A., Gilles, M., and Moffet, R.: Elemental Mixing State of Aerosol Particles Collected in Central Amazonia during GoAmazon2014/15, Atmosphere, 8, 173, https://doi.org/10.3390/atmos8090173, 2017.

Gard, E. E., Kleeman, M. J., Gross, D. S., Hughes, L. S., Allen, J. O., Morrical, B. D., Fergenson, D. P., Dienes, T., E. Gälli, M., Johnson, R. J., Cass, G. R., and Prather, K. A.: Direct Observation of Heterogeneous Chemistry in the Atmosphere, Science, 279, 1184-1187, https://doi.org/10.1126/science.279.5354.1184, 1998.

Glicker, H. S., Lawler, M. J., Ortega, J., de Sá, S. S., Martin, S. T., Artaxo, P., Vega Bustillos, O., de Souza, R., Tota, J., Carlton, A., and Smith, J. N.: Chemical composition of ultrafine aerosol particles in central Amazonia during the wet season, Atmos. Chem. Phys., 19, 13053-13066, https://doi.org/10.5194/acp-19-130532019, 2019.

GoAmazon Science Team: Campaign data sets, available at: https: //www.arm.gov/research/campaigns/amf2014goamazon, last access: 20 October 2020.

Graham, B., Guyon, P., Maenhaut, W., Taylor, P. E., Ebert, M., Matthias-Maser, S., Mayol-Bracero, O. L., Godoi, R. H. M., Artaxo, P., Meixner, F. X., Moura, M. A. L., Rocha, C. H. E. D. A., Grieken, R. V., Glovsky, M. M., Flagan, R. C., and Andreae, M. O.: Composition and diurnal variability of the natural Amazonian aerosol, J. Geophys. Res.-Atmos., 108, 4765, https://doi.org/10.1029/2003jd004049, 2003.

Huffman, J. A., Sinha, B., Garland, R. M., Snee-Pollmann, A., Gunthe, S. S., Artaxo, P., Martin, S. T., Andreae, M. O., and Pöschl, U.: Size distributions and temporal variations of biological aerosol particles in the Amazon rainforest characterized by microscopy and real-time UV-APS fluorescence techniques during AMAZE-08, Atmos. Chem. Phys., 12, 11997-12019, https://doi.org/10.5194/acp-12-11997-2012, 2012.

Ishii, M., Shouji, A., Sugimoto, S., and Matsumoto, T.: Objective analyses of sea-surface temperature and marine meteorological variables for the 20th century using ICOADS and the Kobe Collection, Int. J. Climatol., 25, 865-879, https://doi.org/10.1002/joc.1169, 2005.
Kaiser, J. W., Heil, A., Andreae, M. O., Benedetti, A., Chubarova, N., Jones, L., Morcrette, J.-J., Razinger, M., Schultz, M. G., Suttie, M., and van der Werf, G. R.: Biomass burning emissions estimated with a global fire assimilation system based on observed fire radiative power, Biogeosciences, 9, 527-554, https://doi.org/10.5194/bg-9-527-2012, 2012.

Kobayashi, S., Ota, Y., Harada, Y., Ebita, A., Moriya, M., Onoda, H., Onogi, K., Kamahori, H., Kobayashi, C., Endo, H., Miyaoka, K., and Takahashi, K.: The JRA-55 Reanalysis: General Specifications and Basic Characteristics, J. Meteorol. Soc. Jpn. 93, 5-48, https://doi.org/10.2151/jmsj.2015-001, 2015.

Krejci, R., Ström, J., de Reus, M., and Sahle, W.: Single particle analysis of the accumulation mode aerosol over the northeast Amazonian tropical rain forest, Surinam, South America, Atmos. Chem. Phys., 5, 3331-3344, https://doi.org/10.5194/acp-5-33312005, 2005.

Lamarque, J.-F., Bond, T. C., Eyring, V., Granier, C., Heil, A., Klimont, Z., Lee, D., Liousse, C., Mieville, A., Owen, B., Schultz, M. G., Shindell, D., Smith, S. J., Stehfest, E., Van Aardenne, J., Cooper, O. R., Kainuma, M., Mahowald, N., McConnell, J. R., Naik, V., Riahi, K., and van Vuuren, D. P.: Historical (1850-2000) gridded anthropogenic and biomass burning emissions of reactive gases and aerosols: methodology and application, Atmos. Chem. Phys., 10, 7017-7039, https://doi.org/10.5194/acp-10-7017-2010, 2010.

Li, J., Pósfai, M., Hobbs, P. V., and Buseck, P. R.: Individual aerosol particles from biomass burning in southern Africa: 2, Compositions and aging of inorganic particles, J. Geophys. Res.-Atmos., 108, 8484, https://doi.org/10.1029/2002jd002310, 2003.

Li, W., Shao, L., Zhang, D., Ro, C.-U., Hu, M., Bi, X., Geng, H., Matsuki, A., Niu, H., and Chen, J.: A review of single aerosol particle studies in the atmosphere of East Asia: morphology, mixing state, source, and heterogeneous reactions, J. Clean. Prod., 112, 1330-1349, https://doi.org/10.1016/j.jclepro.2015.04.050, 2016.

Li, W., Liu, L., Xu, L., Zhang, J., Yuan, Q., Ding, X., Hu, W., Fu, P., and Zhang, D.: Overview of primary biological aerosol particles from a Chinese boreal forest: Insight into morphology, size, and mixing state at microscopic scale, Sci. Total Environ., 719 137520, https://doi.org/10.1016/j.scitotenv.2020.137520, 2020.

Martin, S. T., Andreae, M. O., Althausen, D., Artaxo, P., Baars, H., Borrmann, S., Chen, Q., Farmer, D. K., Guenther, A., Gunthe, S. S., Jimenez, J. L., Karl, T., Longo, K., Manzi, A., Müller, T., Pauliquevis, T., Petters, M. D., Prenni, A. J., Pöschl, U., Rizzo, L. V., Schneider, J., Smith, J. N., Swietlicki, E., Tota, J., Wang, J., Wiedensohler, A., and Zorn, S. R.: An overview of the Amazonian Aerosol Characterization Experiment 2008 (AMAZE-08), Atmos. Chem. Phys., 10, 1141511438, https://doi.org/10.5194/acp-10-11415-2010, 2010a.

Martin, S. T., Andreae, M. O., Artaxo, P., Baumgardner, D., Chen, Q., Goldstein, A. H., Guenther, A., Heald, C. L., Mayol-Bracero, O. L., McMurry, P. H., Pauliquevis, T., Pöschl, U., Prather, K. A., Roberts, G. C., Saleska, S. R., Silva Dias, M. A., Spracklen, D. V., Swietlicki, E., and Trebs, I.: Sources and properties of Amazonian aerosol particles, Rev. Geophys., 48, RG2002, https://doi.org/10.1029/2008rg000280, 2010b.

Martin, S. T., Artaxo, P., Machado, L. A. T., Manzi, A. O., Souza, R. A. F., Schumacher, C., Wang, J., Andreae, M. O., Barbosa, H. M. J., Fan, J., Fisch, G., Goldstein, A. H., Guenther, A., Jimenez, J. 
L., Pöschl, U., Silva Dias, M. A., Smith, J. N., and Wendisch, M.: Introduction: Observations and Modeling of the Green Ocean Amazon (GoAmazon2014/5), Atmos. Chem. Phys., 16, 47854797, https://doi.org/10.5194/acp-16-4785-2016, 2016.

Martin, S. T., Artaxo, P., Machado, L., Manzi, A. O., Souza, R. A. F., Schumacher, C., Wang, J., Biscaro, T., Brito, J., Calheiros, A., Jardine, K., Medeiros, A., Portela, B., Sá, S. S. d., Adachi, K., Aiken, A. C., Albrecht, R., Alexander, L., Andreae, M. O., Barbosa, H. M. J., Buseck, P., Chand, D., Comstock, J. M., Day, D. A., Dubey, M., Fan, J., Fast, J., Fisch, G., Fortner, E., Giangrande, S., Gilles, M., Goldstein, A. H., Guenther, A., Hubbe, J., Jensen, M., Jimenez, J. L., Keutsch, F. N., Kim, S., Kuang, C., Laskin, A., McKinney, K., Mei, F., Miller, M., Nascimento, R., Pauliquevis, T., Pekour, M., Peres, J., Petäjä, T., Pöhlker, C., Pöschl, U., Rizzo, L., Schmid, B., Shilling, J. E., Dias, M. A. S., Smith, J. N., Tomlinson, J. M., Tóta, J., and Wendisch, M.: The Green Ocean Amazon Experiment (GoAmazon2014/5) Observes Pollution Affecting Gases, Aerosols, Clouds, and Rainfall over the Rain Forest, B. Am. Meteorol. Soc., 98, 981-997, https://doi.org/10.1175/bams-d-15-00221.1, 2017.

Mather, J. H. and Voyles, J. W.: The Arm Climate Research Facility: A Review of Structure and Capabilities, B. Am. Meteorol. Soc., 94, 377-392, https://doi.org/10.1175/bams-d-11-00218.1, 2013.

Moran-Zuloaga, D., Ditas, F., Walter, D., Saturno, J., Brito, J., Carbone, S., Chi, X., Hrabě de Angelis, I., Baars, H., Godoi, R. H. M., Heese, B., Holanda, B. A., Lavrič, J. V., Martin, S. T., Ming, J., Pöhlker, M. L., Ruckteschler, N., Su, H., Wang, Y., Wang, Q., Wang, Z., Weber, B., Wolff, S., Artaxo, P., Pöschl, U., Andreae, M. O., and Pöhlker, C.: Long-term study on coarse mode aerosols in the Amazon rain forest with the frequent intrusion of Saharan dust plumes, Atmos. Chem. Phys., 18, 10055-10088, https://doi.org/10.5194/acp-18-10055-2018, 2018.

Oshima, N., Koike, M., Zhang, Y., Kondo, Y., Moteki, N., Takegawa, N., and Miyazaki, Y.: Aging of black carbon in outflow from anthropogenic sources using a mixing state resolved model: Model development and evaluation, J. Geophys. Res.Atmos., 114, D06210, https://doi.org/10.1029/2008jd010680, 2009.

Oshima, N., Yukimoto, S., Deushi, M., Koshiro, T., Kawai, H., Tanaka, T. Y., and Yoshida, K.: Global and Arctic effective radiative forcing of anthropogenic gases and aerosols in MRI-ESM2.0, Prog. Earth Planet. Sc., 7, 38, https://doi.org/10.1186/s40645-020-00348-w, 2020.

Pöhlker, C., Wiedemann, K. T., Sinha, B., Shiraiwa, M., Gunthe, S. S., Smith, M., Su, H., Artaxo, P., Chen, Q., Cheng, Y., Elbert, W., Gilles, M. K., Kilcoyne, A. L. D., Moffet, R. C., Weigand, M., Martin, S. T., Pöschl, U., and Andreae, M. O.: Biogenic Potassium Salt Particles as Seeds for Secondary Organic Aerosol in the Amazon, Science, 337, 1075-1078, https://doi.org/10.1126/science.1223264, 2012.

Pöschl, U., Martin, S. T., Sinha, B., Chen, Q., Gunthe, S. S., Huffman, J. A., Borrmann, S., Farmer, D. K., Garland, R. M., Helas, G., Jimenez, J. L., King, S. M., Manzi, A., Mikhailov, E., Pauliquevis, T., Petters, M. D., Prenni, A. J., Roldin, P., Rose, D., Schneider, J., Su, H., Zorn, S. R., Artaxo, P., and Andreae, M. O.: Rainforest Aerosols as Biogenic Nuclei of Clouds and Precipitation in the Amazon, Science, 329, 15131516, https://doi.org/10.1126/science.1191056, 2010.
Prenni, A. J., Petters, M. D., Kreidenweis, S. M., Heald, C. L., Martin, S. T., Artaxo, P., Garland, R. M., Wollny, A. G., and Pöschl, U.: Relative roles of biogenic emissions and Saharan dust as ice nuclei in the Amazon basin, Nat. Geosci., 2, 402-405, https://doi.org/10.1038/ngeo517, 2009.

Rizzolo, J. A., Barbosa, C. G. G., Borillo, G. C., Godoi, A. F. L., Souza, R. A. F., Andreoli, R. V., Manzi, A. O., Sá, M. O., Alves, E. G., Pöhlker, C., Angelis, I. H., Ditas, F., Saturno, J., MoranZuloaga, D., Rizzo, L. V., Rosário, N. E., Pauliquevis, T., Santos, R. M. N., Yamamoto, C. I., Andreae, M. O., Artaxo, P., Taylor, P. E., and Godoi, R. H. M.: Soluble iron nutrients in Saharan dust over the central Amazon rainforest, Atmos. Chem. Phys., 17, 2673-2687, https://doi.org/10.5194/acp-17-2673-2017, 2017.

Saturno, J., Holanda, B. A., Pöhlker, C., Ditas, F., Wang, Q., Moran-Zuloaga, D., Brito, J., Carbone, S., Cheng, Y., Chi, X., Ditas, J., Hoffmann, T., Hrabe de Angelis, I., Könemann, T., Lavrič, J. V., Ma, N., Ming, J., Paulsen, H., Pöhlker, M. L., Rizzo, L. V., Schlag, P., Su, H., Walter, D., Wolff, S., Zhang, Y., Artaxo, P., Pöschl, U., and Andreae, M. O.: Black and brown carbon over central Amazonia: long-term aerosol measurements at the ATTO site, Atmos. Chem. Phys., 18, 1281712843, https://doi.org/10.5194/acp-18-12817-2018, 2018.

Swap, R., Garstang, M., Greco, S., Talbot, R., and Kållberg, P.: Saharan dust in the Amazon Basin, Tellus B, 44, 133-149, https://doi.org/10.3402/tellusb.v44i2.15434, 1992.

Tanaka, T. Y. and Chiba, M.: Global simulation of dust aerosol with a chemical transport model, MASINGAR, J. Meteorol. Soc. Jpn., 83A, 255-278, 2005.

Wang, J., Krejci, R., Giangrande, S., Kuang, C., Barbosa, H. M., Brito, J., Carbone, S., Chi, X., Comstock, J., Ditas, F., Lavric, J., Manninen, H. E., Mei, F., Moran-Zuloaga, D., Pohlker, C., Pohlker, M. L., Saturno, J., Schmid, B., Souza, R. A., Springston, S. R., Tomlinson, J. M., Toto, T., Walter, D., Wimmer, D., Smith, J. N., Kulmala, M., Machado, L. A., Artaxo, P., Andreae, M. O., Petaja, T., and Martin, S. T.: Amazon boundary layer aerosol concentration sustained by vertical transport during rainfall, Nature, 539, 416-419, https://doi.org/10.1038/nature19819, 2016 a.

Wang, Q., Saturno, J., Chi, X., Walter, D., Lavric, J. V., Moran-Zuloaga, D., Ditas, F., Pöhlker, C., Brito, J., Carbone, S., Artaxo, P., and Andreae, M. O.: Modeling investigation of light-absorbing aerosols in the Amazon Basin during the wet season, Atmos. Chem. Phys., 16, 14775-14794, https://doi.org/10.5194/acp-16-14775-2016, 2016 b.

Whitehead, J. D., Darbyshire, E., Brito, J., Barbosa, H. M. J., Crawford, I., Stern, R., Gallagher, M. W., Kaye, P. H., Allan, J. D., Coe, H., Artaxo, P., and McFiggans, G.: Biogenic cloud nuclei in the central Amazon during the transition from wet to dry season, Atmos. Chem. Phys., 16, 9727-9743, https://doi.org/10.5194/acp-16-9727-2016, 2016.

Wittmaack, K.: Brochosomes produced by leafhoppers - a widely unknown, yet highly abundant species of bioaerosols in ambient air, Atmos. Environ., 39, 1173-1180, https://doi.org/10.1016/j.atmosenv.2004.11.003, 2005.

Worobiec, A., Szalóki, I., Osán, J., Maenhaut, W., Anna Stefaniak, E., and Van Grieken, R.: Characterisation of Amazon Basin aerosols at the individual particle level by X-ray microanalytical techniques, Atmos. Environ., 41, 9217-9230, https://doi.org/10.1016/j.atmosenv.2007.07.056, 2007. 
Wu, L., Li, X., Kim, H., Geng, H., Godoi, R. H. M., Barbosa, C. G. G., Godoi, A. F. L., Yamamoto, C. I., de Souza, R. A. F., Pöhlker, C., Andreae, M. O., and Ro, C.-U.: Single-particle characterization of aerosols collected at a remote site in the Amazonian rainforest and an urban site in Manaus, Brazil, Atmos. Chem. Phys., 19, 1221-1240, https://doi.org/10.5194/acp19-1221-2019, 2019.

Yokelson, R. J., Urbanski, S. P., Atlas, E. L., Toohey, D. W., Alvarado, E. C., Crounse, J. D., Wennberg, P. O., Fisher, M. E., Wold, C. E., Campos, T. L., Adachi, K., Buseck, P. R., and Hao, W. M.: Emissions from forest fires near Mexico City, Atmos. Chem. Phys., 7, 5569-5584, https://doi.org/10.5194/acp-7-55692007, 2007.

Yoshizue, M., Iwamoto, Y., Adachi, K., Kato, S., Sun, S., Miura, K., and Uematsu, M.: Individual particle analysis of marine aerosols collected during the North-South transect cruise in the Pacific Ocean and its marginal seas, J. Oceanogr., 75, 513-524, https://doi.org/10.1007/s10872-019-00519-4, 2019.
Yu, H., Chin, M., Yuan, T., Bian, H., Remer, L. A., Prospero, J. M., Omar, A., Winker, D., Yang, Y., Zhang, Y., Zhang, Z., and Zhao, C.: The fertilizing role of African dust in the Amazon rainforest: A first multiyear assessment based on data from Cloud-Aerosol Lidar and Infrared Pathfinder Satellite Observations, Geophys. Res. Lett., 42, 1984-1991, https://doi.org/10.1002/2015gl063040, 2015.

Yukimoto, S., Kawai, H., Koshiro, T., Oshima, N., Yoshida, K., Urakawa, S., Tsujino, H., Deushi, M., Tanaka, T., Hosaka, M., Yabu, S., Yoshimura, H., Shindo, E., Mizuta, R., Obata, A., Adachi, Y., and Ishii, M.: The Meteorological Research Institute Earth System Model version 2.0, MRI-ESM2.0: Description and basic evaluation of the physical component, J. Meteorol. Soc. Jpn., 97, 931-965, https://doi.org/10.2151/jmsj.2019-051, 2019.

Yumimoto, K., Tanaka, T. Y., Oshima, N., and Maki, T.: JRAero: the Japanese Reanalysis for Aerosol v1.0, Geosci. Model Dev., 10, 3225-3253, https://doi.org/10.5194/gmd-10-3225-2017, 2017. 